\title{
Ethnic inclusion, democracy, and terrorism
}

\author{
Kristian Skrede Gleditsch \\ University of Essex \& \\ Peace Research Institute Oslo (PRIO) \\ ksg@essex.ac.uk \\ Sara M. T. Polo \\ Rice University \\ sara.polo@rice.edu
}

Acknowledgements: We are grateful for comments and suggestions from Daniel G. Arce M., Alex Braithwaite, Lars-Erik Cederman, Michael Findley, Suthan Krishnarajan, Jørgen Møller, Lasse Lykke Rørbæk, Todd Sandler, William F. Shugart II, Dag Tanneberg, Jacob Tolstrup, and Andrea Ruggeri as well as the anonymous reviewers. Previous versions of this manuscript has been presented at the workshops on "Political Violence and Policy Conference" at the University of Texas Dallas, 19-20 May 2016, "Foundations of Regime Stability and Conflict" at Aarhus University, 2-3 June, 2016 "Conflicts and Institutions" at the University of Genoa, 16-17 June 2016. Gleditsch is grateful for support from the Research Council of Norway (213535/F10) and the European Research Council (313373), and Polo is grateful for support from the Economic and Social Research Council (ES/J500045/1).

[Type text] 


\section{Introduction}

If ethnic and political exclusion cause ethnic terrorism, can reforms promoting greater ethnic inclusion and democracy reduce terrorist risks? Global concern over terrorism and how to reduce the severity of terrorist attacks has been growing. Although much attention has focused on spectacular transnational terrorist events, most recorded terrorist activity tends to be fully domestic, and often tied to ethnic groups with claims against their home government. Previous research has shown that ethnic exclusion and restricted political access can motivate resort to civil war (see, e.g., Asal and Phillips 2016; Cederman et al. 2010, 2013; Gurr 1994; Regan and Norton 2005), and evidence indicates that ethnic accommodation and political reform can reduce the risk of civil war (see Cederman et al. 2016; Gurr 2000). We believe the same logic should apply to ethnic terrorism as well, and we extend this line of research to examine whether ethnic accommodation can reduce terrorism by lessening motivation and expanding opportunities for pursuing alternative tactics.

Although some previous research has examined ethnic exclusion and terrorism (see, e.g., Choi and Piazza 2016), our study differs from the existing literature in a number of ways. First, we focus on specific ethnic groups rather than adopting a country-level perspective. Second, we examine how ethnic terrorism is affected by accommodation or changes in an ethnic group’s political status, based on the concept of access to political power developed by the Ethnic Power Relations (EPR) project, as well as new data linking ethnic groups and terrorist organizations (see Cederman et al. 2016; Polo 2015). We go beyond the question of whether ethnic groups that are excluded/included engage in more/fewer terrorist attacks, and examine whether resort to terrorism by the group declines after accommodation, in particular cases where an ethnic group gains inclusion or sees an end to active discrimination. Previous research has tended to assume a causal symmetry, whereby inclusion must have the opposite effects of exclusion, and the effects of changes towards inclusion simply follow from the difference in levels of terrorism between groups that are already politically included and groups that are excluded from access to political power. Third, we distinguish between how accommodation affects the overall incidence of terrorism and attacks by splinter groups. Accommodation can induce divisions within groups and encourage splinter groups, but we argue that the effects on motivation and opportunities for recruitment should lead to a decline in terrorism overall. Our empirical results provide considerable support for the claim that ethnic terrorism declines in response to accommodation. We also find some evidence that violence can be difficult to eradicate altogether 
especially when there is a history of ethnic terrorist activity. However, even if we see more attacks by splinter groups, the overall number of terrorist attacks generally declines after accommodation.

\section{The past is a foreign country: The decline of terrorism in Western Europe}

The older and largely forgotten record of terrorist activity in Western Europe after 1945 illustrates the relevance of ethnic terrorism and our claim that accommodation can help reduce terrorist violence (see Shughart 2006). Save for the possible exceptions of the Basques in Spain and Catholics in Northern Ireland, Western Europe has not seen much conventional ethnic civil war, but ethno-nationalist terrorist attacks - inspired by anti-colonial struggles - have been common and the dominant form of terrorism in the region. These patterns can be shown more systematically in the database on Terrorism in Western Europe (TWEED), first collected by Engene (1994). Figure 1 displays the trends in the number of attacks and the number killed in attacks over the 1946-2006 period, using the most recent version (see Engene 2004, 2007). Panel (a) shows a very large share of terrorist attacks carried out by organizations espousing ethnonationalist aims, while panel (b) shows that the bulk of terrorism's casualties also stem from attacks by such organizations. The group with the most attacks in TWEED is the Front de la Libération Nationale de la Corse (FLNC), a militant organization advocating Corsican independence from France. However, the data also show a sharp decline in the frequency and severity of ethnic terrorism over the period, and the decline from the spikes in the 1970s and early 1980s appears to precede the end of the Cold War.

[Figure 1 about here]

Many scholars have noted the prevalence of ethnic terrorism in Western Europe. Engene (1994, 2004) argues that ethnically motivated terrorism is caused by problems of political accommodation, and many nation states have alienated distinct ethnic groups, even under democratic constitutions and practices (see also de la Calle 2015; Rokkan and Urwin 1983; Shughart 2006). These ethnic groups are not necessarily formally deprived of political rights or systematically discriminated against, but often have felt marginalized in a nation state with a dominant group. Some groups have pursued national liberation from foreign domination through political violence, and terrorism is a plausible strategy for small groups with few opportunities to take on the state directly through conventional warfare. 
Less attention, however, has been paid to the subsequent decline in ethnic terrorism in Western Europe. Taking the argument on exclusion as the core motive one step further, the decline of ethnic terrorism should be related to identifiable political changes affecting the motivations and opportunities for engaging in terrorist acts.

The evolution of the FLNC and the political status of the Corsicans provides an instructive example of how greater accommodation appears to have reduced ethnic terrorism. French authorities have made several concessions to expand Corsican autonomy (see Fazi 2014). An independent assembly was set up in 1982, and the 1991 Joxe statute provided the new Collectivité Territoriale de Corse with powers more extensive than normal French regional authorities. Subsequent changes have expanded local control over policy areas such as education and culture, and helped increase the use of the Corsican language in schools. Although these concessions fall short of the demands for full independence and a redistribution of "colonial property”, they have reduced the appeal of violent separatism and enlarged the power of conventional political nationalist organizations. The FLNC remained active through the 2000s, but terrorist attacks attributed to the organization have declined dramatically. The group declared a ceasefire in 2014, justified in part by new legislation giving preference to native-born Corsicans in property purchases, as well as statements on how progress in other separatist conflicts in Europe meant that resort to terrorism was "no longer necessary” in the struggle for national liberation. ${ }^{1}$

Other examples also suggest a similar trajectory along which political accommodation is followed by less ethnic terrorist activity. The best known case obviously is the Irish Republican Army in Northern Ireland. Although some fringe Republican organizations have continued to mount terrorist attacks, the terrorism emanating from the province is much lower than before the 1998 Good Friday agreement. In sum, the experiences of ethnic terrorism in Western Europe suggest that ethnic exclusion can promote terrorist activity, and offers support for the idea that efforts to promote inclusion can reduce the intensity of terrorism, even if they do not fully eradicate it.

\section{Exclusion, accommodation, and the decline of terrorism}

\footnotetext{
${ }^{1}$ http://www.lefigaro.fr/flash-actu/2014/06/25/

97001-20140625FILWWW00292-corse-le-flnc-annonce-lacher-les-armes.php.
} 
The experiences of Western Europe could of course be unique, but we believe that the mechanisms suggested above should be applicable more generally and to other regions in the world. Our arguments are rooted in an analytical perspective wherein non-state actors choose terrorism to coerce a government into granting concessions (see Polo and Gleditsch 2016; Landes 1978; Sandler 2014). If ethnic exclusion motivates resort to terrorism on behalf of ethnic groups, then shifts away from discrimination and toward inclusion should also have the potential to reduce incentives for terrorist attacks, raise the attractiveness of other, non-violent strategies for expressing grievances, and undermine the ability of terrorist organizations to recruit active participants. Moreover, we should be able to observe such effects on ethnic terrorist activities, given the major political changes that have taken place around the globe towards greater political openness and accommodation, especially after the Cold War.

In the following sections we first review prior research on ethnic exclusion and political violence. We highlight the limitations of country-level studies of ethnic terrorism and the need to look at specific groups to establish the impact of their political status. We then turn to the prospects for reducing conflict through ethnic inclusion or accommodation. We develop testable hypotheses on terrorist attack frequency, given group characteristics and accommodation. We also acknowledge that violence can be path dependent and that there may be important limits to the ability to reduce violence through accommodation, and we develop specific propositions on the effects of accommodation on attacks by splinter groups and overall levels of terrorism.

\subsection{Ethnic exclusion and terrorism}

A large literature exists on how exclusion motivates ethnic civil war (see, e.g., Cederman et al. 2013). These arguments should in our view also extend to ethnic terrorism, although we have less direct global research on that topic. Some scholars have examined the relationship between ethnic diversity and terrorism and find at best limited evidence for a relationship (e.g., Kurrild-Klitgaard et al. 2006). However, these studies rely on purely demographic measures of ethnicity such as fractionalization indices based on the size and number of groups that provide no information on the political status of ethnic groups or the degree of political exclusion or discrimination. A state could have limited ethnic diversity but high exclusion - as in contemporary Syria, where the small Alawite group dominates power to the exclusion of the majority Sunni - or high diversity without political exclusion of any groups, as in contemporary South Africa. Moreover, 
whereas ethnic demography is essentially fixed and cannot change, at least in the short run, the political status of an ethnic group can change dramatically, as shown by the example of South Africa pre/postApartheid. ${ }^{2}$ Beyond the older studies of ethnic terrorism in Europe (see Engene 1994, 2004), Piazza (2012) provided one of the first global studies explicitly identifying the political status of ethnic groups, using data from the Minorities at Risk project, but found no evidence that political discrimination against minorities had discernible effects on the number of domestic terrorist attacks. However, in a more recent study using information from the Ethnic Power Relations data, Choi and Piazza (2016) demonstrate that countries with large, politically excluded ethnic populations are more likely to experience terrorist attacks and suffer more casualties from terrorism. The size of the ethnically excluded population is a clear advance on the binary indicators of discriminated or disadvantaged groups used in previous studies, and better reflects motives and opportunities for mobilization and resort to terrorism. Yet, focusing on countries at large obscures the role of group agency and how the political status of an ethnic group affects behavior. For example, if both ethnic and other grievances stem from governments that are generally exclusive, then we may simply see more terrorism in general in countries with ethnic exclusion, but not necessarily ethnically motivated terrorism or attacks perpetrated by the excluded group. As an extreme example of misplaced agency, we could see organizations associated with dominant groups using terrorism to intimidate excluded groups, perhaps to prevent political mobilization. Plausible examples of this include hate crime against minority groups in the United States and South Africa.

Unlike previous research on terrorism, we apply a group perspective to ethnic terrorism. We expect that ethnic groups have potential grievances or motivations to engage in terrorism when they are excluded from political influence or lack autonomy (Cederman et al. 2013). We believe that the relationship between ethnic exclusion and violence should apply even more strongly to terrorist violence than to civil war, given differences in the opportunities for and the feasibility of tactics. The wide resource asymmetries between ethnic groups and the state should make organizations linked to ethnic groups particularly likely to engage in terrorism, as the covert nature of terrorist tactics makes it possible to evade

\footnotetext{
${ }^{2}$ Basuchoudhary and Shughart (2010) examine how a perception based measure of ethnic tensions influence transnational terrorism. Although this will reflect variation in ethnic relations and terrorism, it does not allow assessing to what extent political status may drive ethnic tensions.
} 
state repression and target more powerful opponents when conventional warfare is unrealistic or unlikely to be effective (see Findley and Young 2012; Polo and Gleditsch 2016). This observation is consistent with how Corsican organizations turned to terrorism outside the context of a conventional civil war. Moreover, organizations linked to politically excluded ethnic groups are more likely to see noncombatants associated with dominant ethnic groups as legitimate targets or acceptable collateral casualties in terrorist attacks.

\subsection{Accommodation and ethnic terrorism}

Existing research has looked only at how current ethnic exclusion from political power is associated with terrorism and not whether changes away from active discrimination or towards inclusion can reduce ethnic terrorism. If ethnic exclusion induces stronger incentives for terrorism, then we should also expect shifts in the direction of inclusiveness to reduce the motivation for terrorism. The existing arguments on the effects of exclusion could be read as suggesting that any reduction in exclusion or move toward inclusion should likewise lessen terrorist activity, but this issue thus far has not attracted much direct theoretical or empirical attention. As we note later, accommodation may also have limited ability to reduce terrorism when violent ethnic organizations have been established.

Reforms to bring greater inclusion could come in two different types. First, and most directly, we can have group-specific accommodation, or changes in the political status of an ethnic group previously disadvantaged relative to a politically privileged ethnic group. Group-specific accommodation could include granting access to power for the group at the executive level (for example, by including an ethnically based party in a governing coalition), possibly in collaboration with other groups, concessions offering regional autonomy, or reductions in overt discrimination against the group. Second, we could have general political accommodation or reforms that reduce exclusion more broadly. For example, in an autocratic regime where most individuals are deprived of political rights, transitions to democracy will expand opportunities for political action on behalf of ethnic groups.

Improvements in the political status of an ethnic group should reduce terrorist attacks by lessening motives for violent action directly, as in the case of moves away from active discrimination, and expanding the ability of the group to influence outcomes by non-violent means, following the power proximity logic highlighted by Cederman et al. (2015). Similarly, democratization should weaken the incentives of ethnic 
groups to resort to terrorism by expanding opportunities to voice their grievances and pursue their interests by non-violent political means, such as voting (see Crenshaw 1981; Gurr 1994; Sandler et al. 1983). Ethnic accommodation and democracy as means of political inclusion are conceptually and empirically distinct. Many examples of power sharing in non-democracies exist, such as Malaysia (where Chinese and Indians also enjoy some political influence, alongside the Malays), while some states with competitive elections restrict political access or ban separatist claims on behalf of ethnic groups (such as Turkey with respect to the Kurds). However, it is generally much easier for ethnic groups to advance their interests in a democracy and more difficult for governments to deny a group political rights (see Gurr 2000).

Changes in political status also will influence the ability of ethnic organizations to recruit for political violence. From a general spatial modeling perspective, any concessions towards greater ethnic inclusion should satisfy some group members and induce substitution away from violence after accommodation (DeNardo 1985). Existing models of the growth trajectory of terrorist organizations show that attack patterns over time are shaped strongly by recruitment (Asal and Rethemeyer 2008; Clauset and Gleditsch 2012). Given some rate of attrition, organizations with better prospects for sustained recruitment are able to carry out more attacks, at a higher frequency, and wage more persistent terrorist campaigns. Thus, organizations who seek to continue violence on behalf of an ethnic group will find it more difficult to recruit participants after accommodation, as long as it satisfies a sufficient number of individuals in their audience. This should lead to a decline in the ability of the organization to maintain a high number of terrorist attacks.

If ethnic accommodation can reduce ethnic terrorism, then we should be able to observe such effects in light of the major changes observed around the world. First, the so-called third wave of democracy has seen transitions in many countries once believed unlikely to move away from autocratic rule (see Gleditsch and Ward 2006; Huntington 1993). Second, and much less well-known, we also have major ethno-political accommodation and conflict management after the Cold War (see Cederman et al. 2013; Gurr 1994, 2000). Gurr (2000) argued that greater group accommodation has promoted a waning of ethnic warfare, and Cederman et al. (2016) demonstrate more systematically that ethnic accommodation appears to reduce the 
risk of ethnic conflict onset and promote conflict termination. So far, however, the effects of ethnic accommodation on terrorism have not been examined directly.

We detail the specific measures and testable hypotheses relating accommodation and terrorism below. However, we first turn to possible limits on accommodation's ability to reduce violence, as well as potentially important differences between terrorism and civil war.

\subsection{Limits to accommodation in reducing violence}

There are a number of reasons why we may not expect a direct casual symmetry whereby a positive effect of exclusion on terrorism implies a negative effect of inclusion. First, a large literature has reached very pessimistic conclusions about the permissive effects of democracy on terrorism, highlighting how lower repression can make it easier to carry out terrorist attacks, as well as how greater media freedom increases the publicity for attacks and thus may raise incentives for terrorism (e.g., Eubank and Weinberg 1994). Many empirical studies conclude that democracy can have ambiguous consequences for terrorism (see Chenoweth 2010, 2013; Li 2005; Piazza 2013), although these studies do not consider ethnic accommodation or ethnic terrorism per se.

Second, research on group-specific accommodation in conventional conflict often emphasizes the path-dependence of violence. It is well-known that conflict tends to recur, and research on conflict management shows that it is often difficult to eradicate violence altogether through accommodation or peace agreements once violent organizations are established (e.g., Horowitz 2014; Roeder and Rothchild 2005). Leaders in established organizations can have incentives to further their own interests by continuing violence, or individuals in the group’s constituency may become desensitized and more accepting of the use of violence. Thus, even if accommodating institutions are associated with peace in stable societies, they could give rise to perverse incentives that exacerbate conflict when there is a history of violence. Cederman et al. (2015), for example, find that regional autonomy arrangements can prevent the recurrence of conflict only if combined with power sharing or political access to the central government. Ash (2016) argues that post-transition democracies will see more domestic terrorism as insurgent groups switch to terrorism, even if terrorist campaigns are more evident (and persistent) in semi-democracies and autocracies.

Finally, the barriers to carry out terrorist attacks are lower than for conventional warfare, and terrorist organizations tend to be less hierarchical than the standing forces engaged in conventional 
conflicts. This may increase commitment problems after accommodation substantially, as even a leadership favorably disposed to a settlement often will have limited ability to control individual participants or to prevent factions from splintering off or carrying out attacks.

\subsection{Accommodation and the incentives of organizations}

Although the existing literature suggests important limits on reducing terrorism through accommodation, we believe that it is too pessimistic and does not pay sufficient attention to differences between groups and to the magnitude of terrorism. Even if some factions intensify terrorist attacks following accommodation and a settlement, the lower opportunities for recruitment will make it more difficult for violent organizations to carry out a sustained high number of attacks thereafter.

Settlements or accommodation usually privilege certain actors and positions in the conflict (e.g., Crenshaw 1981). The precise effects on the incentives for violence depend on the magnitude of the concessions and the distribution of the specific demands within a group. Ethnic accommodation is likely to highlight divergent preferences, ranging from full independence to an acceptance of more limited autonomy under the existing state. In particular, instances wherein an ethnic group is offered concessions or accommodation can exacerbate internal divisions within the group (see Seymour et al. 2016). Even if greater political inclusion and concessions to an ethnic group may satisfy moderate members, hardliners may reject anything short of full secession or refuse to share power, or they may prefer to continue violence if they believe that this can help radicalize the group’s audience and raise their organizations profile (see Kydd and Walter 2002). In light of this we expect that attacks by mainstream ethnic organizations are likely to decline following accommodation, but attacks by splinter groups may increase.

However, despite the risk of more attacks by splinter groups, the net effects of accommodation must be judged relative to the overall scale of terrorism. We expect to see a clear decline in total terrorism after accommodation to a group, both owing to mainstream organizations not carrying out attacks and to a reduced ability to sustain fringe terrorist campaigns. Even if hardliners/splinters wish to carry out many attacks after accommodation, they will have limited ability to recruit or amass resources to do so. A similar pattern has been noted for civil war in that accommodation may not fully eradicate civil war, but the 
remaining violence tends to be less severe and often involves small splinter groups (see Gleditsch and Hegre 2014). However, the effects of accommodation on different organizations have so far not been examined in the case of ethnic terrorism.

\section{Does ethnic accommodation decrease ethnic terrorism? An empirical analysis}

\subsection{Data, measures, and hypotheses}

We measure ethnic terrorism at the group level using a new dataset (GTD2EPR) that relates terrorist organizations in the Global Terrorism Database (GTD) to ethnic groups in the Ethnic Power Relations (EPR) project, based on whether organizations make public claims - or are held to make implicit claims on behalf of a specific ethnic group (see Polo 2015). The approach is conceptually similar to the ACD2EPR data, relating organizations in civil conflict in the Uppsala Armed Conflict Data (ACD) to EPR groups (see Wucherpfennig et al. 2012). This makes it possible to look systematically at all groups as the unit of analysis, including cases wherein no terrorist organizations are associated with a group. The dataset comprises 766 EPR groups in total, over the period. ${ }^{3}$

For our main analyses, we aggregate all domestic terrorist attacks by organizations linked to a specific EPR group in each year. We believe the number of terrorist attacks per ethnic-group-country-year provides a better measure of terrorist intentions than other alternative measures. A simple binary gauge of terrorism, flagging any terrorist attack by organizations associated with an ethnic group, is completely insensitive to the magnitude of attacks. This is especially problematic for testing the effects of accommodation, as it would disregard any reduction in terrorism unless the number of attacks goes to exactly zero. It is essential to look at overall attack incidence, as splinter groups or fringe organizations make it unlikely that terrorism will disappear completely in the context of a history of ethnic terrorist activity. Severity or the number of people killed in attacks is in our view a separate issue than willingness to resort to terrorism. It potentially depends on whether organizations seek or try to avoid large numbers of

\footnotetext{
${ }^{3}$ We exclude transnational attacks since we focus on how ethnic exclusion and accommodation influence domestic terrorist events. The total number of ethnic groups varies across years, and can change if new independent states emerge (e.g., through decolonization or secession), or the EPR data classify a change in ethnic distinctions within a country.
} 
casualties (see Asal and Rethemeyer 2008), or the actual number killed or injured in an attack may to a large extent be stochastic rather than premeditated (see Clauset et al. 2007; Clauset and Gleditsch 2012).

We measure accommodation in terms of changes in the political status of ethnic groups and democracy more generally. We use indicators of the political statuses of ethnic groups from the Ethnic Power Relations (EPR) data (Cederman et al. 2010). Our measure of active discrimination is simply whether a group is classified as discriminated against, and any move away from this is considered accommodation. We define active inclusion slightly differently than the standard EPR definition, which focuses exclusively on power at the national level. We treat groups as actively included if they either enjoy a monopoly, are dominant, or a junior or senior partner in power-sharing, and also include cases where a group has regional autonomy. In the analysis of changes, we identify observations where a group moves up to the active inclusion category. For general democracy we use the Polity dataset (Jaggers and Gurr 1995). For the analysis on levels we use the full 21-point Polity institutionalized democracy scale. We identify transitions to democracy by changes from a Polity score from below to above 6, based on the suggested threshold for democracy by Jaggers and Gurr (1995).

With these measures in hand we are now ready to define more precise hypotheses:

- Movements away from active exclusion and discrimination of an ethnic group should reduce terrorist activity by organizations associated with the group.

- Movements toward active inclusion of an ethnic group should lessen terrorist activity by organizations associated with the group.

- Transitions to democracy should reduce ethnic terrorism.

- Attacks by ethnic splinter organizations will rise following movements away from active discrimination against the ethnic group.

- Attacks by ethnic splinter organizations will escalate following steps toward active inclusion of the ethnic group.

We also add controls for other country-specific characteristics found to influence levels of terrorism. Terrorism often overlaps with civil war, which also is likely to be associated with ethnic 
exclusion and autocracy (see Findley and Young 2012; Polo and Gleditsch 2016). We thus enter a variable for ongoing civil war based on the Uppsala Armed Conflict Data (Gleditsch et al. 2002). We control for relative group size as a proportion of total population from EPR, since group size is likely to determine the feasibility and attractiveness of terrorism relative to conventional conflict. Moreover, we also consider country-level factors plausibly associated with accommodation and terrorism, such as logged total population and GDP per capita, using the most recent data from Gleditsch (2002). ${ }^{4}$ Since the GTD data are missing for 1993, we drop that year from our analyses.

The data at hand are not without limitations for testing our arguments about ethnic accommodation and terrorism. The EPR data is the only dataset to assess political status systematically for ethnic groups, including majority and dominant groups. However, EPR's concept of what constitutes an ethnic group is somewhat restrictive, and excludes many smaller ethnic groups with terrorist records such as the Bretons in France, where the militant Armée Révolutionnaire Bretonne (ARB) has carried out a number of terrorist attacks. Moreover, the ethnic exclusion and inclusion measures focus mainly on access to power at the national level. For some groups this may be less relevant than concessions at the local level, along with some recognition of national distinctiveness or language rights, such as the reforms in Corsica. Still, even if the thresholds may ignore lower-level concessions, we should still observe a clear impact following recorded major accommodations.

Trending in the terrorism data can create problems of comparability over time. Some argue that much of the apparent increase in terrorism in sources such as the GTD dataset may be explained by better reporting and more inclusive coding (Human Security Report 2007). However, although the GTD data may suffer from trends and reporting biases, positive trending over time would in practice make it more difficult to observe an effect of accommodation on subsequent attacks, since a rising trend in terrorism runs counter

\footnotetext{
${ }^{4}$ We have also considered possible non-linear effects of regime type, but found no evidence that this specification changed the main results or notably improved the fit of the model. We provide these results in the supplementary appendix.
} 
to the observed positive developments in accommodation over the same period, and thus bias the results against finding support for our hypotheses.

\subsection{Empirical analysis}

We first briefly review the trends in ethnic terrorism in the GTD2EPR data and how they fit with trends in accommodation. Figure 2 shows some evidence that ethnic terrorism has declined after the mid-1990s or the period of ethnic accommodation identified by Gurr (2000). Although we see an increase in ethnic terrorism after September 11, 2001, much of this increase is driven by terrorism within civil wars, especially Afghanistan and Iraq. Table 1 shows the ten most active ethnic groups over the period, by total terrorist attacks and maximum attacks by year.

[Figure 2 and Table 1 about here]

Before turning to the effects of changes in ethnic accommodation on resort to terrorism we examine the relationship between ethnic exclusion/inclusion and the frequency of terrorist attack at the group level. Only $18 \%$ of the ethnic groups in our dataset have some record of terrorism. More than two-thirds of all terrorist attacks in the full sample are carried out by ethnic groups that are politically excluded, and over one-third of the groups that have faced active discrimination have associated organizations that have carried out attacks at some point. However, these relationships between political status and terrorism could possibly reflect other factors associated with both political status and propensity to use terrorism, and we thus estimate in Table 2 negative binomial regression models of the number of attacks as a function of political status and the suggested control variables. The negative binomial is an event count model that allows for overdispersion, commonly used in studies with the number of terrorist attacks as the response (e.g., SantifortJordan and Sandler 2014). We report non-parametric bootstrapped standard errors based on 1000 samples throughout to guard against the consequences of serial dependence and heteroscedasticity (and which are more appropriate than asymptotically based alternatives, given the limited number of observations in the 
subsequent change analysis; see Gonçalves and White 2005).

[Table 2 about here]

The estimates in column 1 of Table 2 show we see more attacks mounted by discriminated against ethnic groups. By contrast, column 2 indicates that politically included ethnic groups carry out fewer attacks, but the negative coefficient is not statistically significant. The results in columns 1 and 2 cover all EPR groups, including groups not considered politically relevant. ${ }^{5}$ This could be problematic for testing the effects of active inclusion, as many excluded groups are not mobilized for political action. When we replicate the analyses for politically relevant groups only, we continue to find a strong effect of active discrimination in column 3, and we now find a much stronger and more clearly statistically significant effect of active inclusion in column 4. Moreover, the negative estimated coefficient for group size turns positive or insignificant when we exclude groups that are not politically relevant (and generally smaller in size). Inclusion is not the opposite of discrimination, and the reference categories for the models are different. A discriminated group can by definition not be included, but there are many excluded groups that are not actively discriminated against. Furthermore, inclusion is not synonymous with democratic institutions. Although a majority (54\%) of the ethnic-group-year observations in democracies are politically included, as many as $46 \%$ of the ethnic-group-year observations in non-democracies also have access to political power. Nor is it the case that discrimination never occurs in a democracy, although the share is lower than in non-democracies (8.9\% versus $13.1 \%)$.

To illustrate the substantive effects, we display in Figure 3 the distribution of the expected numbers

\footnotetext{
${ }^{5}$ According to the EPR codebook, “an ethnic group is politically relevant if either at least one significant political actor claims to represent the interests of that group in the national political arena or if group members are systematically and intentionally discriminated against in the domain of public politics”; see http://www.icr.ethz.ch/data/epr/EPR-2014_Codebook.pdf.
} 
of terrorist attacks in a year for discriminated against and included groups, holding all other values at their means, based on 1000 draws from the model estimates in columns 3 and 4. As can be seen, the expected number of attacks by discriminated against ethnic groups on average almost doubles compared to nondiscriminated groups, whereas attacks fall by about 38\% when groups are included relative to politically excluded groups.

Although the results support a negative effect of group-specific accommodation we find much less evidence for democracy inducing substitution away from terrorism, and the coefficient is always significantly positive. The positive effect could be interpreted to mean that the facilitating effects of democracy simply outweigh any accommodative effects. ${ }^{6}$ Although this is possible, we suspect that the findings may be driven by some specific democracies with frequent ethnic terrorism by smaller groups, such as India, Indonesia, and Spain. ${ }^{7}$ More generally, the results for levels of ethnic inclusion/exclusion and ethnic terrorism in Table 2 may reflect primarily cross-sectional variation between groups. For example, many included groups without attacks may drive the results, and if so then these results would not help capture the effects of accommodation or changes in political status. The results may be also sensitive to the general problem of omitted variables plausibly associated with the regressors and the response, possibly country-specific differences not fully captured by the control variables.

[Figure 3 about here]

\footnotetext{
${ }^{6}$ Alternatively, democracy as competitive political institutions may be less relevant to terrorism than other forms of liberal constitutions such as the rule of law and economic freedom (see Basuchoudhary and Shughart 2010 for evidence on transnational terrorism).

${ }^{7}$ We show in the appendix that there is some evidence for an interaction between democracy and group size, such that larger groups are less likely to use terrorism in democracies (the effect turns negative when relative group size is above the mean, i.e., 0.19). This is consistent with a logic wherein the impact of democracy varies depending on the potential power that a group can wield. However, a fuller analysis would need to consider other factors, such as electoral systems/representation and opportunities for conventional violence.
} 
Fixed effects models provide one way to leverage changes occurring specifically within units, as all time-invariant features particular to individual groups or countries drop out when we take first differences. There is no generally accepted fixed effects negative binomial estimator owing to the problem of incidental parameters, and the conditional negative binomial does not constitute a true fixed-effects estimator or fully account for unit heterogeneity (see Alison and Waterman 2002; Green 2005). To include fixed effects it is thus preferable to use a simple normal linear regression with the logged number of attacks, after adding 1 to the base, so that the log transformation helps to correct for the skewness and provides a more plausible functional form (see also Bove and Böhmelt 2016). Model 1 in Table 3 shows similar results for discrimination and inclusion, thus indicating that the previous findings are not simply explained by crosssectional variation, but also obtain when we focus exclusively on changes within countries. Most notably, we observe a sign reversal for democracy and now find a statistically significant negative coefficient. This lends some support to our concern that the previous positive coefficient in levels may stem from countryspecific omitted factors, and that changes in democracy in general tend to reduce terrorism. Model 2 in Table 3 shows generally similar results when we add fixed effects for individual years, which would take into account potentially non-linear time trends, although the democracy coefficient loses statistical significance. In Model 3 we restrict the analysis to politically relevant groups only, and the coefficient for democracy becomes statistically significant again. In the supplementary appendix we further show similar results for multilevel mixed effects negative binomial models, which can be considered an alternative approach to unit-heterogeneity (see Gelman and Hill 2007).

Although fixed effects estimates are restricted to variation within countries, they are not ideally suited to examine the effects of accommodation per se, as they implicitly assume that changes in either direction must have symmetric effects. Thus, it is entirely possible that the results primarily reflect the effects of downgrades, where groups that face greater discrimination or undergo transitions to exclusion resort to terrorism. In order to examine the effects of upgrades on the number of attacks specifically we use a more complicated research design, and try to emulate counterfactuals by restricting the analysis to cases for which an ethnic group has engaged in terrorism before, and either was upgraded, or could have received an upgrade. Examining the differences in the number of attacks after upgrades against the baseline of 
similar groups without changes gives a plausible estimate of the effects of accommodation. The results of these analyses are provided in Table $4 .^{8}$

[Tables 3 and 4 about here]

As can be seen in column 1 in Table 4, we find that a move away from active discrimination leads to fewer expected attacks, and the negative coefficient is statistically significant. To give some sense of the magnitude of the results we consider the difference in the predicted values for the observed data given the model estimates compared to the predicted values for a counterfactual scenario, without all the moves towards accommodation that have taken place over the period, leaving other covariates at the same values. We find a difference of approximately 1800 additional predicted terrorist attacks over the period, or an increase of more than $60 \%$ relative to the predicted number of terrorist attacks for the actual observations involving shifts away from discrimination. This seems substantively large, and suggests that we would have seen a great deal more ethnic terrorism with active discrimination still in place. Figure 4 maps the distribution of the additional predicted attacks in the absence of accommodation, highlighting a much larger expected number of attacks for groups, such as the previously excluded groups in South Africa, in the absence of reductions in active discrimination.

For upgrades to inclusion we also find a negative, albeit not statistically significant effect. The

${ }^{8}$ Our argument here is not that changes in accommodation are exogenous or unrelated to past terrorist activity by the group, but we simply try to evaluate the consequences of political status on motivation and attacks. It is entirely possible that terrorism by a group may push a government to provide accommodation, but it seems implausible that anticipated lower terrorism should promote concessions. Accommodation could conceivably increase terrorist activity if terrorist organizations were largely insensitive to any gains in status or perceived that more terrorism could bring yet larger future concessions. Our results, however, do not support this. 
predictions under the counterfactual with no changes in the observed data suggest over 800 additional attacks absent accommodation. The effect of transitions to democracy actually is positive. This is reminiscent of the findings for the original model in levels, but difficult to reconcile with the fixed effect results for which democratization had a negative effect. Re-analyses to examine whether any individual country or region seemed to drive the results indicate that the apparent positive effect of transitions to democracy appear to stem entirely from some Asian countries with substantial terrorism after transitions, including, for example, Indonesia, Nepal and the Philippines. Indeed, we get a negative coefficient estimate for transitions to democracy when the model is estimated for all other regions, either individually, or without the Asian countries, as shown in column 4 in Table 5, indicating less terrorism after transitions. ${ }^{9}$ Figure 5 compares the substantive effect of accommodation and of transitions to democracy, based on 1000 simulations from the estimates in column 1 and 4, holding all other values at the mean or mode. As a group ceases to be discriminated against the expected number of terrorist attacks drops by almost $40 \%$, whereas attacks decline by 28\% following transitions to democracy, not including Asia.

[Figures 4 and 5 about here]

The fact that the opposite results obtain for transitions to democracy outside Asia raises questions about whether the pooled results can be considered characteristic, even if many groups in Asian countries see increased terrorism following transitions. We also believe that these results provide support for the idea that democracy often has reduced terrorist activity. Investigating more systematically the possible differences in ethnic relations and institutions that may underlie this finding is beyond the scope of this article, but we believe that one possible explanation is that many of these Asian countries have small and marginalized groups in their peripheries that continue to see themselves as excluded and face active discrimination, with little attention by central governments controlled by a clearly dominant national group.

\footnotetext{
${ }^{9}$ In the supplementary appendix we provide additional results where we let transitions interact with group size and again find some evidence of interaction. The tipping point is much lower for the sample excluding Asia, and the marginal effect turns negative for groups with a relative size above 0.05 .
} 
As such, democracy provides few opportunities for these small groups to exercise influence, and thus has failed to reduce terrorism so far. However, the Western European experience suggests that democracy in the long-run may help foster recognition of diversity and regional devolution.

Our results for the transition period speak more directly to changes, but may be seen as vulnerable to omitted variables. In Table 5 we repeat the analysis on the full sample using fixed effects, where we can compare the difference for the upgrade period. We find negative coefficients for all the upgrade features in columns 1-3, including transitions to democracy for the full sample. In the supplementary appendix we provide additional results for multilevel models that take into account the hierarchical structure of the data, where individual observations are nested within ethnic groups and multiple groups are present within the same country. We consider a two-level mixed effects negative binomial regression, where intercepts vary by group, and a three-level mixed effects negative binomial where intercepts are modeled as a function of clustered group-level and country-level variables (see Gelman and Hill 2007). The results for accommodation remain consistent, and we find a significant negative effect of transitions to democracy throughout, as in the fixed effects estimates.

[Table 5 about here]

We have argued that ethnic accommodation should reduce overall terrorism and attacks by mainstream organizations, but extremists and splinter groups may step up efforts. A number of practical challenges are encountered in testing this proposition. The term splinter group is often used to denote both when organizations emerge as well as their relative position, which is difficult to establish on a systematic comparative basis. We essentially bypass these problems here by a simple analysis that relies entirely on the chronology of organizations associated with an ethnic group. We distinguish between the "first" organization associated with an ethnic group recorded with an attack in the GTD data, and treat all “subsequent” groups as splinter groups. This approach has a number of limitations. Later terrorist groups may not necessarily be more extreme, and one could envision that a moderate faction splits from an existing 
group before accommodation and reduces its terrorist activities more than the "first" group. This approach also disregards all terrorist activity before the first year in the data (1970), coding all groups present at the outset as "first", even though their actual founding dates and trajectories may differ. Moreover, any group active later will by definition be regarded as a splinter if prior activity has been recorded for the group, even if unrelated to the prior organization. The FLNC discussed above was clearly the dominant Corsican group, but would show up as a "splinter" group by the simplistic distinctions used here, as it resulted from a merger of two previous groups.

Despite all these caveats, we still find some evidence that attacks by splinter groups become more common in the post-accommodation period in Table 6, both for moves away from discrimination and moves toward active inclusion. We see these results as consistent with our claim that, while terrorism declines overall, it may not fall to exactly zero, and the effects of accommodation on the terrorist activity of individual groups will be conditional on their relative positions and possible competition with other groups.

\section{[Table 6 about here]}

\section{Discussion and conclusion}

We started by asking whether ethno-political relations structure the motives and opportunities for ethnic terrorism and whether reforms can reduce ethnic terrorism. Our analyses provide a number of novel results regarding ethnic terrorism at the group and organizational level. For ethnic groups at large, our results indicate that overall levels of ethnic terrorism appear to respond to group-specific accommodation, as the magnitude or frequency of terrorism clearly declines. We also find some support for transitions to democracy reducing ethnic terrorism, although the results here are heterogeneous and more ambiguous. Our study suggests a more nuanced understanding of the relationship between ethnic group accommodation, political reform, and resort to terrorism, as individual organizations will respond differently to accommodation, based on their goals and incentives. Many moderate groups stand to benefit from a more inclusive political system and become more likely to give up terrorist activity. However, splinter groups 
with more extreme goals may reject settlements and continue to resort to terrorism. As such, accommodation may not eradicate terrorism completely. Some splinter groups may persist and possibly elevate their violent activities precisely to resist accommodation, or exploit additional opportunities and media attention to destabilize the existing regime further. However, any such increases in splinter terror are not sufficient to offset the overall decline from reductions in violence by mainstream groups.

We acknowledge that the time period we study is limited, but we believe that our theoretical arguments on the effects of accommodation should extend beyond the specific period as well as the data and measures considered here, as long as accommodation goes some way towards satisfying mainstream groups and the distribution of individual preferences makes it sufficiently difficult to recruit large numbers of fighters for terrorist organizations with more extreme aims. The divergent findings for Asian countries highlight the possible benefits of analyzing in more detail how the incentives of ethnic terrorism are shaped by the structure of the state and the specific role of the group, and how reforms and institutional design can promote inclusion or engagement with groups. It may be possible to expand the empirical analysis by integrating other information on terrorism with a longer perspective and more differentiated measures of ethic status, including smaller groups not in the EPR dataset. These other groups may not engage in civil war or large-scale violence, but many still have records of terrorist activity, and may respond to a wider range of accommodation strategies other than accessing power at the central level.

With respect to policy, our findings that reductions in ethnic discrimination and reforms promoting inclusion of previously marginalized groups can reduce the number of ethnic terrorist attacks offer support for strategies that focus on political engagement over purely repressive responses (see, e.g., Cederman et al. 2013; Gurr 1994, 2000; Mack 2002; Shughart 2006). Unlike many questionable counterterrorism efforts known to entail large costs, political strategies promoting accommodation of ethnic differences could potentially be cost-effective and stable solutions to ethnic terrorism (see Mueller and Stewart 2016). That is not to say, however, that accommodation may not be politically costly to governments. There is often a strong reluctance to "reward" terrorist organizations, and resistance from privileged ethnic groups and 
interests that emphasize the unity of the state can conceivably make it difficult for governments to make concessions to marginalized ethnic groups. However, we believe that the experiences of Western Europe indicate that such costs can be moderated and contained by framing and emphasizing their positive longterm consequences. Making concessions to ethnic groups that have resorted to terrorism does not mean that terrorist tactics "win” if they reduce future terrorism. Rather than encouraging adverse selection, we think that strategies of accommodation often help marginalize and undermine extremists. Moreover, ethnic accommodation need not be a zero-sum game. Although such concessions may have been controversial in the past, the long-term benefits of reducing political violence and future disruption eventually have helped overcome resistance to concessions and accommodation among dominant groups in Western Europe, to the point where they are less inclined to see this as threatening to their interests. Just as terrorist tactics can diffuse through successful examples (see Polo 2015), so can conflict settlements and ethnic accommodation (see Cederman et al. 2015). 


\section{References}

Alison, P.D., \& Waterman R.P. (2002). Fixed-effects negative binomial regression models. Sociological Methodology 32(1), 247-265.

Asal, V., \& Phillips, B.J. (2016). What explains ethnic organizational violence? Evidence from Eastern Europe and Russia. Conflict Management and Peace Science, forthcoming.

Asal, V., \& Rethemeyer, R.K. (2008). The nature of the beast: Organizational structures and the lethality of terrorist attacks. Journal of Politics 70(2), 437-449.

Ash, K. (2016). Representative democracy and fighting domestic terrorism. Terrorism and Political Violence 28(1), 114-134.

Basuchoudhary, S., \& Shughart, W.F. (2010). 'on ethnic conflict and the origins of transnational terrorism. Defence and Peace Economics 21(1), 65-87.

Bove, V., \& Böhmelt, T. (2016). Does immigration induce terrorism? Journal of Politics 78(2), 572-588.

Cederman, L-E, Wimmer, A., \& Min, B. (2010). Why do ethnic groups rebel? New data and analysis. World Politics 62(1), 87-119.

Cederman, L-E., Gleditsch, K.S., \& Buhaug, H. (2013). Inequality, grievances, and civil war. New York: Cambridge University Press.

Cederman, L-E., Gleditsch, K.S., \& Wucherpfennig. J. (2015). The Diffusion of Inclusion. Paper presented 25 
at the annual meeting of the American Political Science Association.

Cederman, L-E, Gleditsch, K.S., \& Wucherpfennig, J. (2016). Predicting the decline of ethnic civil war: Was Gurr right and for the right reasons? Journal of Peace Research, forthcoming.

Cederman, L-E, Hug, S., Schädel, A., \& Wucherpfennig, J. (2015). Territorial autonomy in the shadow of conflict: Too little, too late? American Political Science Review 109(2), 354-370.

Chenoweth, E. (2010). Democratic competition and terrorist activity. Journal of Politics 72(1), 16-30.

Chenoweth, E. (2013). Terrorism and democracy. Annual Review of Political Science 16, 355-378.

Choi, S.-W., \& Piazza, J.A. (2016). Ethnic groups, political exclusion and domestic terrorism. Defence and Peace Economics 27(1), 37-63.

Clauset, A., \& Gleditsch, K.S. (2012). The developmental dynamics of terrorist organizations. PLoS One 7(11), e48633.

Clauset, A., Young, M., \& Gleditsch, K.S. (2007). On the frequency of severe terrorist events. Journal of Conflict Resolution 51(1), 1-31.

Crenshaw, M. (1981). The causes of terrorism. Comparative Politics 13(4), 379-399.

de la Calle, L. (2015). Nationalist violence in postwar Europe. Cambridge: Cambridge University Press. 
DeNardo, J. (1985). Power in numbers: The strategy of protest and rebellion. Princeton, NJ: Princeton University Press.

Engene, J.O. (1994). Europeisk terrrorisme: Vold, state og legitimitet. Oslo: TANO.

Engene, J.O. (2004). Terrorism in Western Europe: Explaining the trends since 1950. Cheltenham: Edward Elgar.

Engene, J.O. (2007). Five decades of terrorism in Europe: The TWEED dataset. Journal of Peace Research 44(1), 109-121.

Eubank, W.L., \& Weinberg, L. (1994). Does democracy encourage terrorism? Terrorism and Political Violence 6(4), 417-435.

Fazi, A. (2014). The multilevel politics of accommodation and the non-constitutional moment: Lessons from Corsica. In Lluch, J. (ed.) Constitutionalism and the politics of accommodation in multinational democracies (pp. 132-155). Basingstoke: Palgrave.

Findley, M.G., \& Young, J.K. (2012). Terrorism and civil war: A spatial and temporal approach to a conceptual problem. Perspectives on Politics 10(2), 285-305.

Gelman, A., \& Hill, J. (2007). Data analysis using regression and multilevel/hierarchical models. New York: Cambridge University Press.

Gonçalves, S., \& White, H. (2005). Bootstrap standard error estimates for linear regression. Journal of the 
American Statistical Association 100 (471), 970-979.

Gleditsch, K.S. (2002). Expanded trade and GDP data, 1946-99. Journal of Conflict Resolution 46(5), 712724.

Gleditsch, K.S., \& Hegre, H. (2014). Regime type and political transition in civil war. In DeRoen, K. \& Newman, E. (eds) Routledge handbook of civil wars (pp. 145-156). London: Routledge.

Gleditsch, K.S., \& Ward, M.D. (2006). The diffusion of democracy and the international context of democratization. International Organization 60(4), 911-933.

Gleditsch, N.-P., Wallensteen, P., Erikson, M., Sollenberg M., \& Strand, H. (2002). Armed conflict, 194599: A new dataset. Journal of Peace Research 39(5), 615-637.

Green, W. (2005). Functional form and heterogeneity in models for count data. Foundations and trends in econometrics 1, 113-218.

Gurr, T.R. (1994). Peoples against states: Ethnopolitical conflict and the changing world system. International Studies Quarterly 38(3), 347-377.

Gurr, T.R. (2000). Ethnic warfare on the wane. Foreign Affairs 79, 52-64.

Horowitz, D.L. (2014). Ethnic power sharing: Three big problems. Journal of Democracy 25(2), 5-20.

Human Security Report. (2007). Human security brief. http://www.hsrgroup.org/human-security- 
reports/2007/overview.aspx.

Huntington, S.P. 1993. The third wave of democracy. Norman, OK: University of Oklahoma Press.

Jaggers, K., \& Gurr, T.R. (1995). Tracking democracy’s 'third wave’ with the Polity III data. Journal of Peace Research 32(4), 469-82.

Kurrild-Klitgaard, P., Justesen, M.K., \& Klemmensen, R. (2006). The political economy of freedom, democracy and transnational terrorism. Public Choice 128(1/2), 289-315.

Kydd, A., \& Walter, B. (2002). Sabotaging the peace: The politics of extremist violence. International Organization 56(2), 263-296.

Landes, W.M. (1978). An economic study of US aircraft hijackings, 1961-1976. Journal of Law and Economics 21(1), 1-31.

Li, Q. (2005). Does democracy promote or reduce transnational terrorist incidents? Journal of Conflict Resolution 49(2), 278-297.

Mack, A. (2002). Civil war: Academic research and the policy community. Journal of Peace Research 39(5), 515-525.

Mueller, J., \& Stewart, M. (2016). Chasing ghosts: The policing of terrorism. Oxford: Oxford University Press. 
Piazza, J.A. (2012). Types of minority discrimination and terrorism. Conflict Management and Peace Science 29(5), 521-546.

Piazza, J.A. (2013). Regime age and terrorism: Do young democracies experience more terrorist attacks? International Interactions 39(2), 246-263.

Polo, S.M.T. (2015). How terrorism spreads: Information, emulation, and the spatial diffusion of ethnic terrorism. Paper presented at the 2015 Annual Meeting of the American Political Science Association.

Polo, S.M.T., \& Gleditsch, K.S. (2016). Twisting arms to send a message: Terrorism in civil war. Journal of Peace Research, forthcoming.

Regan, P.M., \& Norton, D. (2005). Greed, grievance, and mobilization in civil wars. Journal of Conflict Resolution 49(3), 319-336.

Roeder, P.G. \& Rothchild. D. 2005. Sustainable peace: Democracy and power after civil wars. Ithaca, NY: Cornell University Press.

Rokkan, S., \& Urwin, D.W. (1983). Economy, territory, identity: Politics of west European peripheries. Thousand Oaks, CA: Sage.

Sandler, T. (2014). The analytical study of terrorism: Taking stock. Journal of Peace Research 51(2), 257271.

Sandler, T., Tschirhart, J.T., \& Cauley, J. (1983). A theoretical analysis of transnational terrorism. 
American Political Science Review 77(1), 36-54.

Santifort-Jordan, C., \& Sandler, T. (2014). An empirical study of suicide terrorism: A global analysis. Southern Economic Journal 80(4), 981-1001.

Seymour, L.J.M., Bakke, K.M., \& Cunningham, K.G. (2016). E pluribus unum, ex uno plures: Competition, violence, and fragmentation in ethnopolitical movements. Journal of Peace Research 53(1), 3-18.

Shughart, W.F. II. (2006). An analytical history of terrorism, 1945-2000. Public Choice, 128(1/2), 7-39

Wucherpfennig, J. Metternich, N.W., Cederman. L-E., \& Gleditsch, K.S. (2012). Ethnicity, the state, and the duration of civil wars. World Politics 64(1), 79-115. 
Figures and table

Figure 1: Terrorist attacks and number killed in Western Europe by type

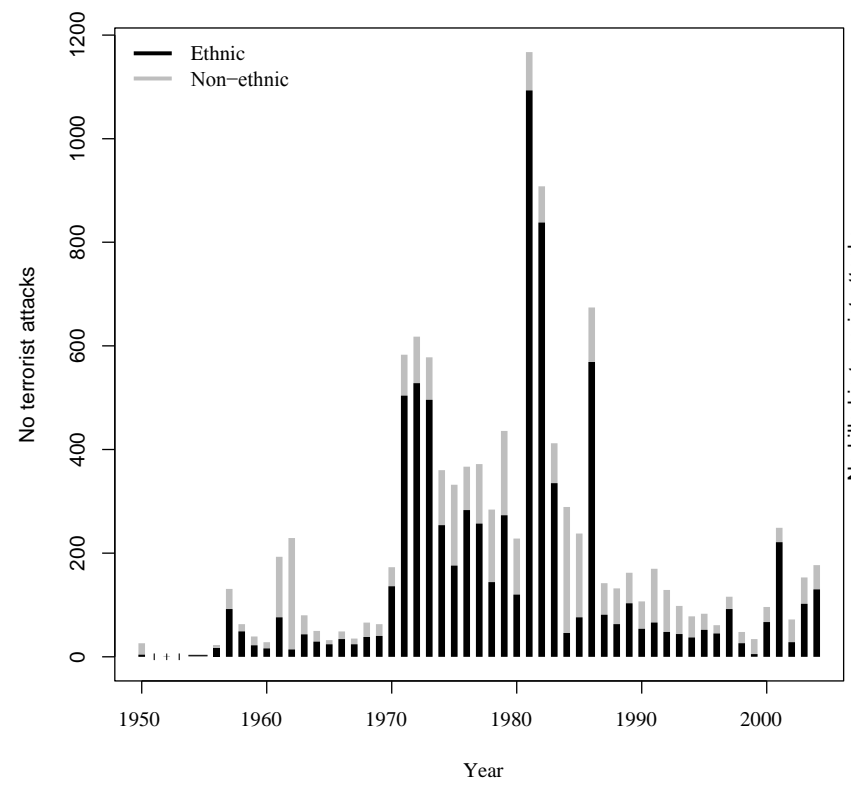

(a) Number of attacks, ethnic vs. non-ethnic

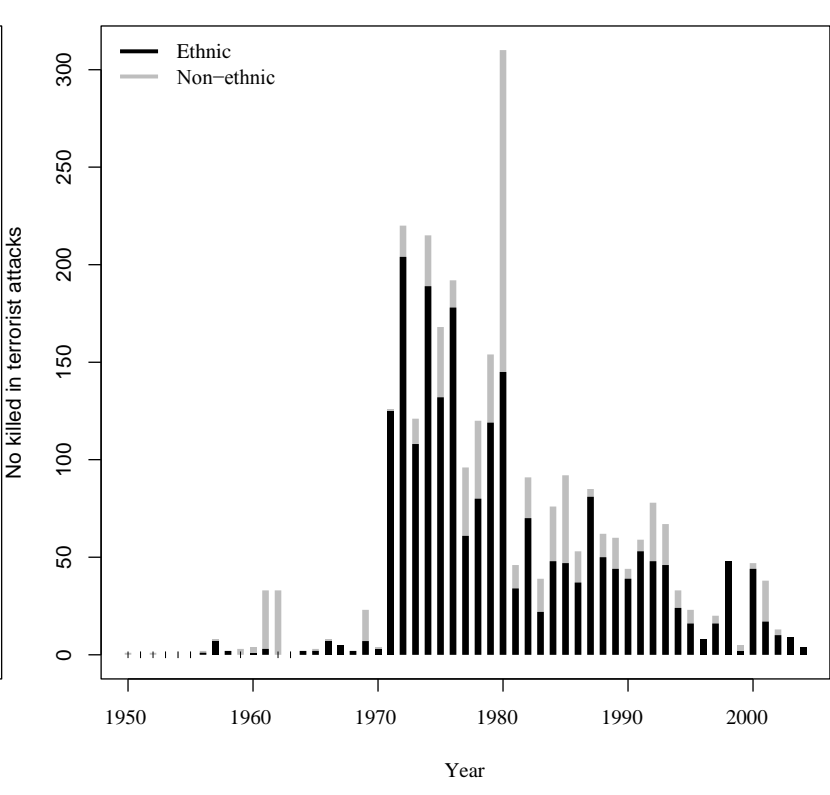

(b) Killed in attacks, ethnic vs. non-ethnic 
Figure 2: Trends in ethnic terrorism

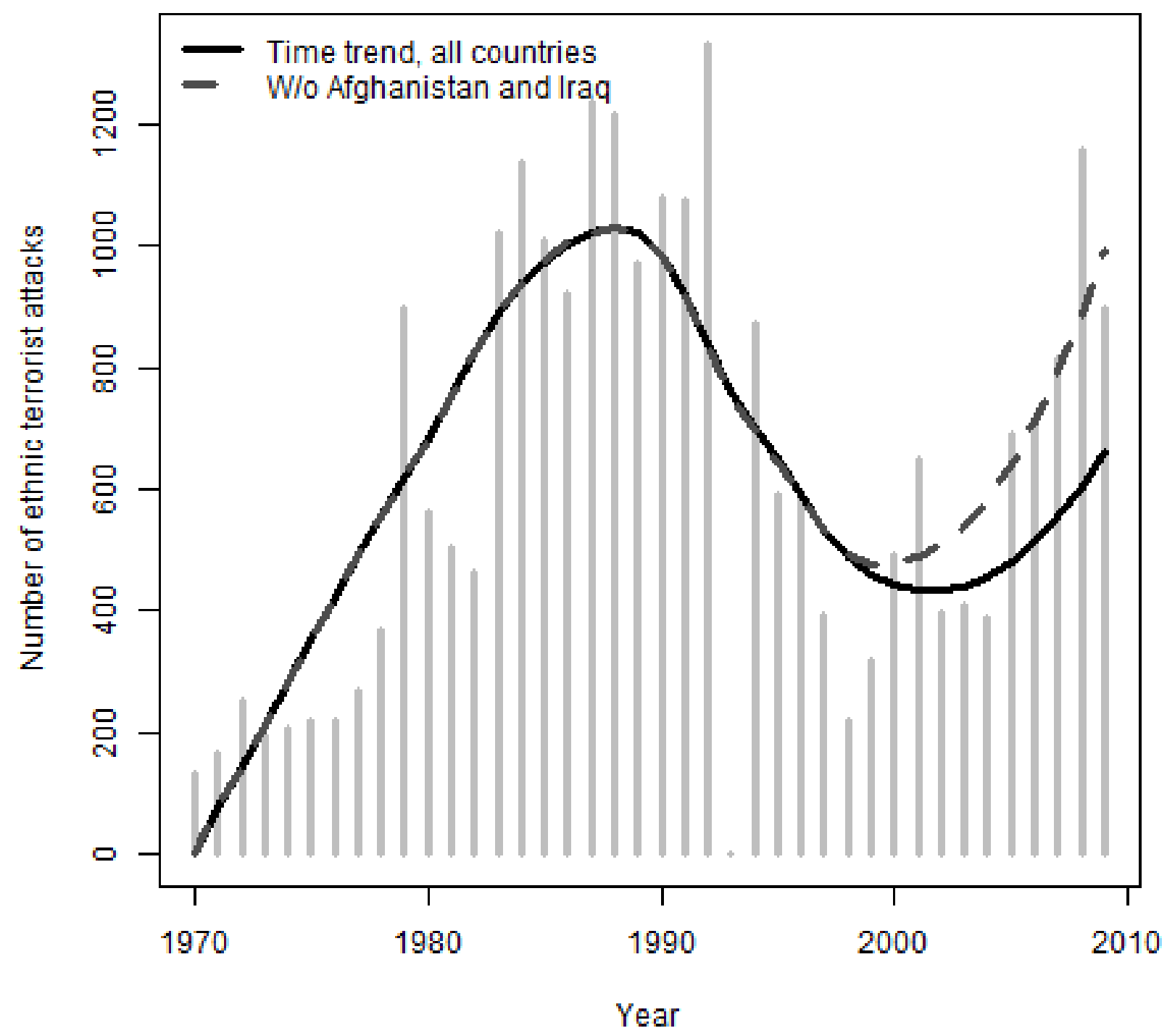


Figure 3: Expected number of attacks for discriminated and included groups
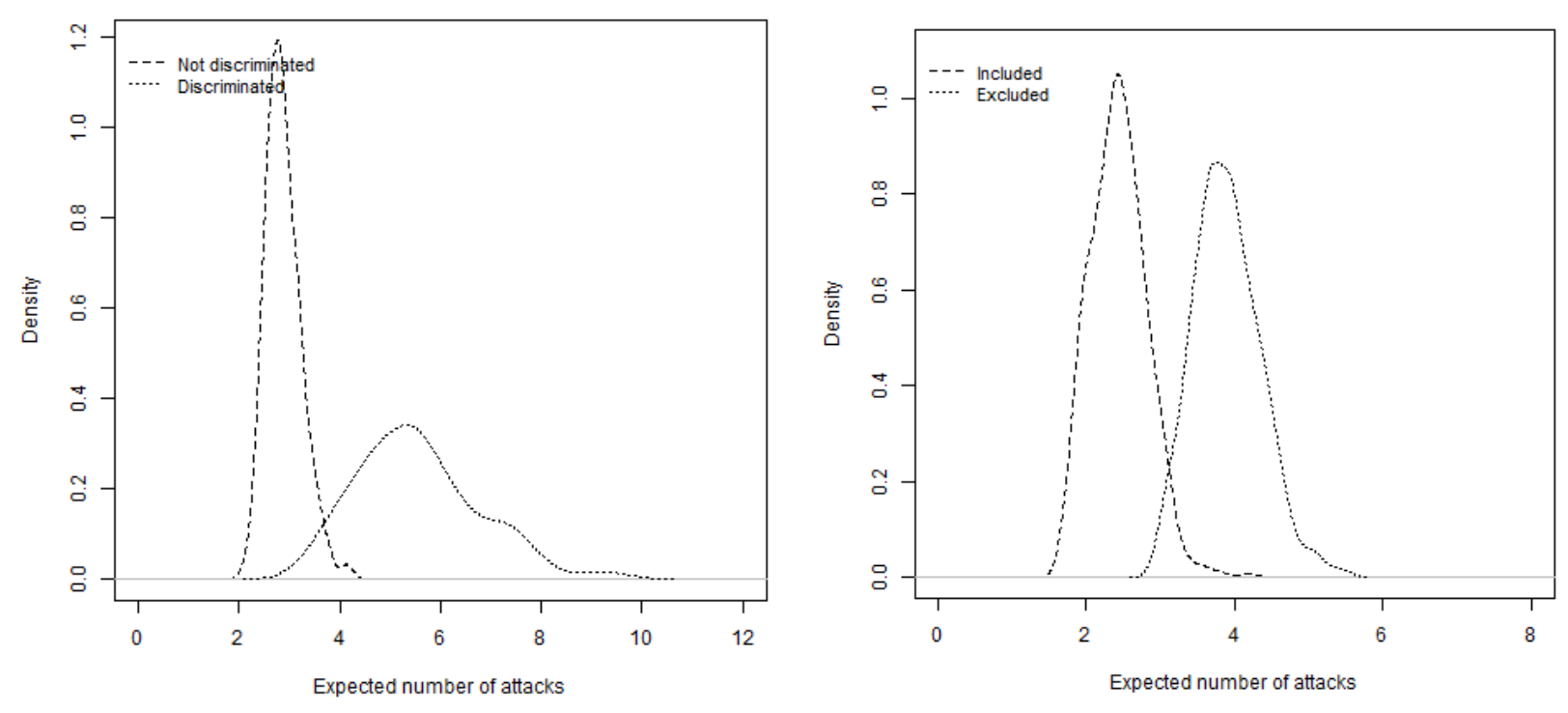
Figure 4: Aggregate additional attacks 1970-2009 by ethnic groups predicted from counterfactual data without changes away from discrimination over the period.

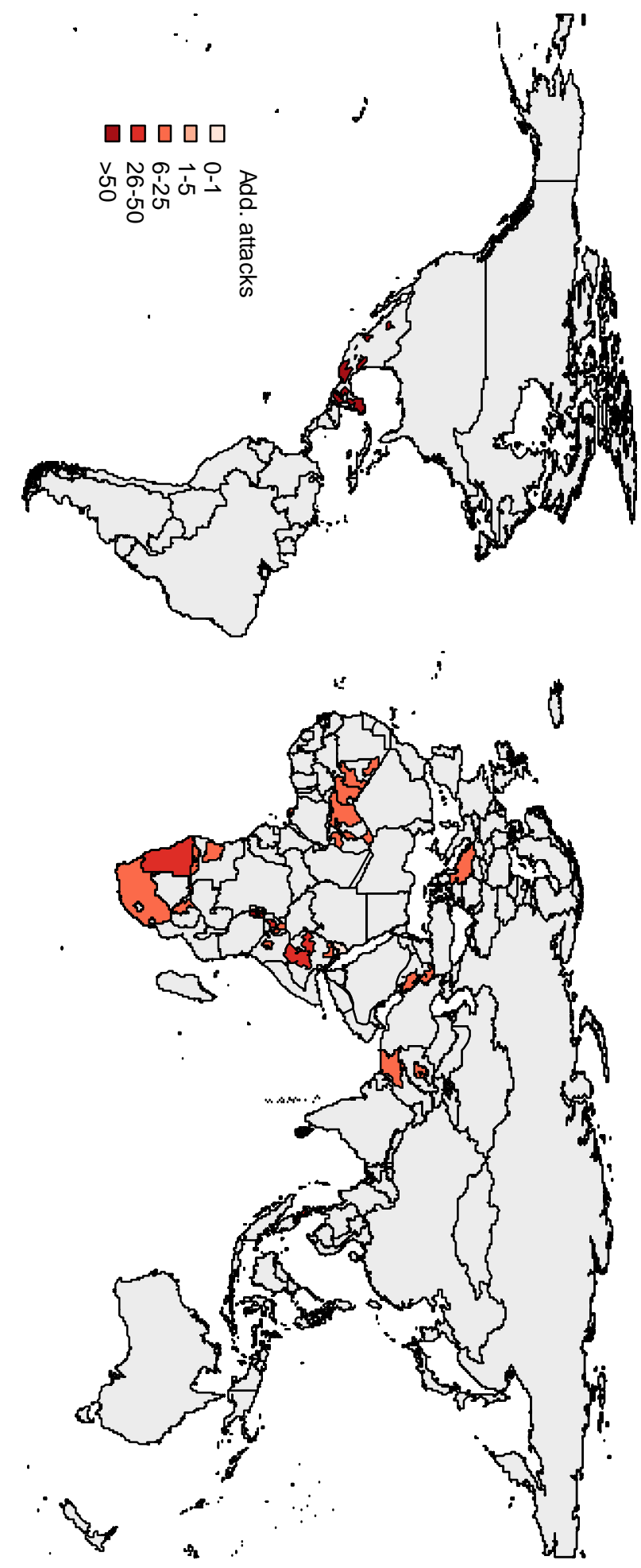


Figure 5: Expected number of terrorist attacks by changes in status and in regime type
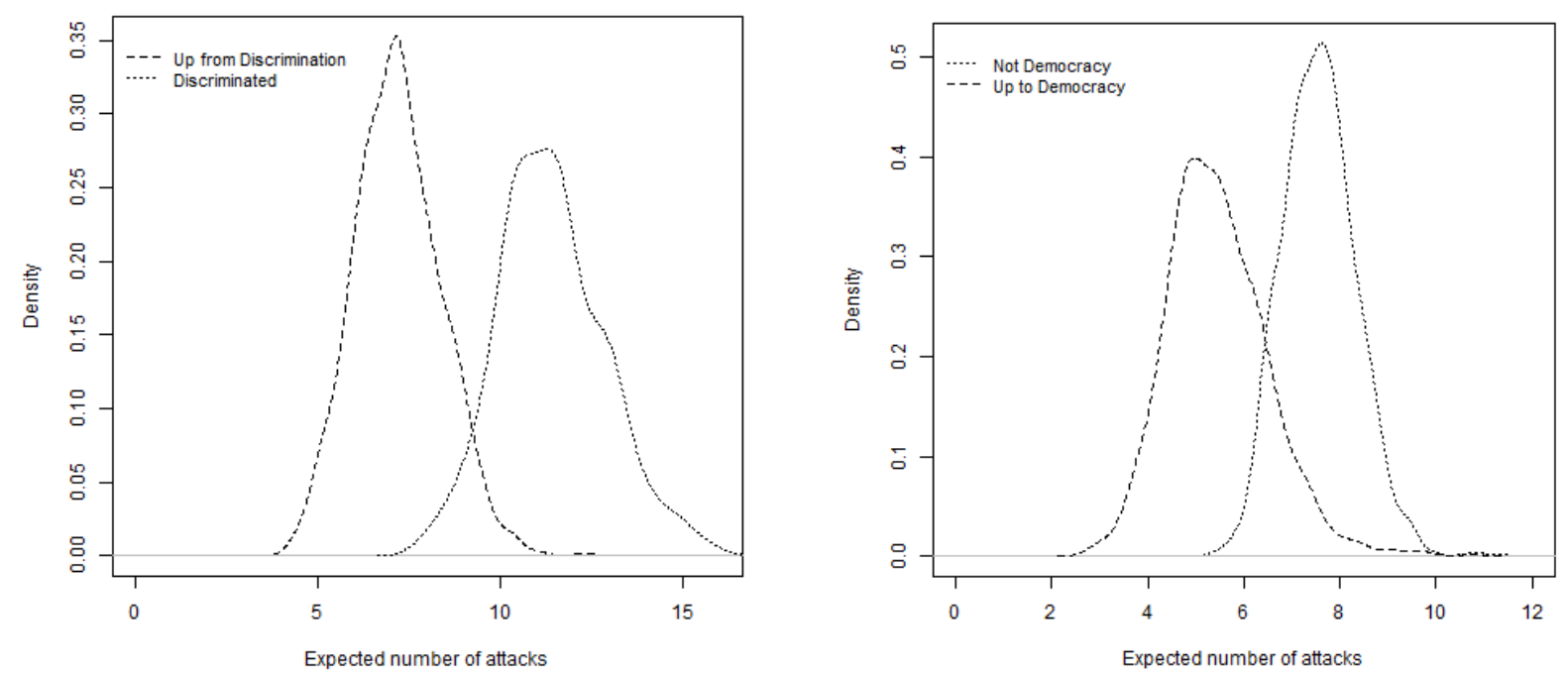
Table 1: 10 most active groups by total terrorist attacks over period and maximum by year

\begin{tabular}{rlrlr}
\hline & Group-country & Total attacks & Group-country & max attacks by year \\
\hline 1 & Catholics In N. Ireland-United Kingdom & 2810 & Kurds-Turkey & 317 \\
2 & Basques-Spain & 1979 & Pashtuns-Afghanistan & 268 \\
3 & Palestinian Arabs-Israel & 1869 & Miskitos-Nicaragua & 242 \\
4 & Sri Lankan Tamils-Sri Lanka & 1829 & Sumus-Nicaragua & 229 \\
5 & Miskitos-Nicaragua & 1152 & Catholics In N. Ireland-United Kingdom & 209 \\
6 & Pashtuns-Afghanistan & 1132 & Ovimbundu-Ovambo-Angola \\
7 & Sumus-Nicaragua & 1114 & Basques-Spain & 197 \\
8 & Kurds-Turkey & 1030 & Pashtuns-Pakistan & 170 \\
9 & Punjabi-Sikhs (non-SC/ST)-India & 798 & Palestinian Arabs-Israel & 161 \\
10 & Moro-Philippines & 682 & Sri Lankan Tamils-Sri Lanka & 159 \\
\hline
\end{tabular}


Table 2: Negative binomial regression, number of attacks by group-years

\begin{tabular}{|c|c|c|c|c|}
\hline & \multicolumn{4}{|c|}{ Dependent variable: } \\
\hline & \multicolumn{4}{|c|}{ attack } \\
\hline & (1) & $(2)$ & (3) & (4) \\
\hline Discriminated & $\begin{array}{l}0.731^{* * *} \\
(0.206)\end{array}$ & & $\begin{array}{l}0.621^{* * *} \\
(0.222)\end{array}$ & \\
\hline Included & & $\begin{array}{l}-0.190 \\
(0.161)\end{array}$ & & $\begin{array}{c}-0.468^{* * *} \\
(0.170)\end{array}$ \\
\hline Polity & $\begin{array}{l}0.054^{* * *} \\
(0.015)\end{array}$ & $\begin{array}{l}0.058^{* * *} \\
(0.015)\end{array}$ & $\begin{array}{l}0.051^{* * *} \\
(0.016)\end{array}$ & $\begin{array}{c}0.057 \\
(0.173)\end{array}$ \\
\hline Civil war & $\begin{array}{l}2.943^{* * *} \\
(0.175)\end{array}$ & $\begin{array}{l}2.948^{* * *} \\
(0.172)\end{array}$ & $\begin{array}{l}3.032^{* * *} \\
(0.184)\end{array}$ & $\begin{array}{l}2.975^{* * *} \\
(0.346)\end{array}$ \\
\hline Group size & $\begin{array}{l}-0.676^{* *} \\
(0.339)\end{array}$ & $\begin{array}{l}-0.533^{*} \\
(0.308)\end{array}$ & $\begin{array}{l}-0.041 \\
(0.364)\end{array}$ & $\begin{array}{l}0.198^{* * *} \\
(0.016)\end{array}$ \\
\hline Ln(population) & $\begin{array}{l}-0.047 \\
(0.060)\end{array}$ & $\begin{array}{l}-0.059 \\
(0.062)\end{array}$ & $\begin{array}{l}-0.005 \\
(0.066)\end{array}$ & $\begin{array}{l}-0.004 \\
(0.068)\end{array}$ \\
\hline Ln(GDPpc) & $\begin{array}{l}0.503^{* * *} \\
(0.091)\end{array}$ & $\begin{array}{l}0.465^{* * *} \\
(0.090)\end{array}$ & $\begin{array}{l}0.589^{* * *} \\
(0.097)\end{array}$ & $\begin{array}{l}0.524^{* * *} \\
(0.096)\end{array}$ \\
\hline Constant & $\begin{array}{c}-5.522^{* * *} \\
(1.071)\end{array}$ & $\begin{array}{c}-4.905^{* * *} \\
(1.095)\end{array}$ & $\begin{array}{c}-6.679^{* * *} \\
(1.161)\end{array}$ & $\begin{array}{c}-5.834^{* * *} \\
(1.200)\end{array}$ \\
\hline Observations & 26,905 & 26,905 & 23,353 & 23,353 \\
\hline Log Likelihood & $-9,163.169$ & $-9,174.262$ & $-8,892.882$ & $-8,892.537$ \\
\hline$\theta$ & $0.016^{* * *}(0.001)$ & $0.016^{* * *}(0.001)$ & $0.019^{* * *}(0.001)$ & $0.019^{* * *}(0.001)$ \\
\hline Akaike Inf. Crit. & $18,340.340$ & $18,362.520$ & $17,799.760$ & $17,799.070$ \\
\hline
\end{tabular}


Table 3: Fixed effects models of log(attacks+1)

\begin{tabular}{|c|c|c|c|}
\hline & \multicolumn{3}{|c|}{ Dependent variable: } \\
\hline & \multicolumn{3}{|c|}{$\log (\operatorname{attack}+1)$} \\
\hline & & With year F.E. & Rel. groups only \\
\hline & (1) & $(2)$ & (3) \\
\hline \multirow[t]{2}{*}{ Discriminated } & $0.069^{* * *}$ & $0.070^{* * *}$ & $0.072^{* * *}$ \\
\hline & $(0.013)$ & $(0.013)$ & $(0.016)$ \\
\hline \multirow[t]{2}{*}{ Included } & $-0.049^{* * *}$ & $-0.050^{* * *}$ & $-0.058^{* * *}$ \\
\hline & $(0.009)$ & $(0.009)$ & $(0.012)$ \\
\hline \multirow[t]{2}{*}{ Polity } & $-0.001^{*}$ & -0.001 & $-0.002^{* *}$ \\
\hline & $(0.001)$ & $(0.001)$ & $(0.001)$ \\
\hline \multirow[t]{2}{*}{ Civil war } & $0.195^{* * *}$ & $0.187^{* * *}$ & $0.228^{* * *}$ \\
\hline & $(0.007)$ & $(0.008)$ & $(0.008)$ \\
\hline \multirow[t]{2}{*}{ Group size } & $0.357^{* *}$ & $0.334^{*}$ & $0.450^{* *}$ \\
\hline & $(0.172)$ & $(0.171)$ & $(0.190)$ \\
\hline \multirow[t]{2}{*}{ Ln(population) } & $0.110^{* * *}$ & $0.088^{* * *}$ & $0.141^{* * *}$ \\
\hline & $(0.009)$ & $(0.013)$ & $(0.011)$ \\
\hline \multirow[t]{2}{*}{ Ln(GDPpc) } & $0.014^{* *}$ & 0.008 & $0.020^{* * *}$ \\
\hline & $(0.007)$ & $(0.007)$ & $(0.008)$ \\
\hline Observations & 27,635 & 27,635 & 23,987 \\
\hline $\mathrm{R}^{2}$ & 0.033 & 0.039 & 0.038 \\
\hline Adjusted $\mathrm{R}^{2}$ & 0.032 & 0.038 & 0.037 \\
\hline F Statistic & $129.235^{* * *}(\mathrm{df}=7 ; 26819)$ & $23.822^{* * *}(\mathrm{df}=46 ; 26780)$ & $132.440^{* * *}(\mathrm{df}=7 ; 23206)$ \\
\hline
\end{tabular}


Table 4: Negative binomial attack by positive changes in relevant cases at risk of accommodation Dependent variable: attack

\begin{tabular}{|c|c|c|c|c|}
\hline & (1) & (2) & (3) & $\begin{array}{c}\text { W/o Asia } \\
\text { (4) }\end{array}$ \\
\hline Up from discrimination & $\begin{array}{l}-0.476^{* *} \\
(0.206)\end{array}$ & & & \\
\hline Up to inclusion & & $\begin{array}{l}-0.161 \\
(0.148)\end{array}$ & & \\
\hline Up to democracy & & & $\begin{array}{l}0.560^{* *} \\
(0.226)\end{array}$ & $\begin{array}{l}-0.344^{*} \\
(0.195)\end{array}$ \\
\hline Polity & $\begin{array}{l}0.123^{* * *} \\
(0.021)\end{array}$ & $\begin{array}{c}0.088^{* * *} \\
(0.013)\end{array}$ & & \\
\hline Civil war & $\begin{array}{l}1.769^{* * *} \\
(0.211)\end{array}$ & $\begin{array}{l}1.672^{* * *} \\
(0.174)\end{array}$ & $\begin{array}{l}1.860^{* * *} \\
(0.157)\end{array}$ & $\begin{array}{l}1.845^{* * *} \\
(0.176)\end{array}$ \\
\hline Group size & $\begin{array}{l}1.902^{* * *} \\
(0.416)\end{array}$ & $\begin{array}{l}0.921^{* * *} \\
(0.306)\end{array}$ & $\begin{array}{l}0.851^{* *} \\
(0.379)\end{array}$ & $\begin{array}{l}0.693^{* *} \\
(0.309)\end{array}$ \\
\hline Ln(population) & $\begin{array}{l}-0.051 \\
(0.117)\end{array}$ & $\begin{array}{c}-0.247^{* * *} \\
(0.054)\end{array}$ & $\begin{array}{c}-0.186^{* * *} \\
(0.067)\end{array}$ & $\begin{array}{c}-0.275^{* * *} \\
(0.093)\end{array}$ \\
\hline Ln(GDPpc) & $\begin{array}{c}0.508^{* * *} \\
(0.116)\end{array}$ & $\begin{array}{c}0.613^{* * *} \\
(0.084)\end{array}$ & $\begin{array}{l}0.662^{* * *} \\
(0.097)\end{array}$ & $\begin{array}{l}1.131^{* * *} \\
(0.083)\end{array}$ \\
\hline Constant & $\begin{array}{l}-3.117^{*} \\
(1.749)\end{array}$ & $\begin{array}{l}-1.844^{*} \\
(1.103)\end{array}$ & $\begin{array}{c}-3.148^{* * *} \\
(1.113)\end{array}$ & $\begin{array}{c}-6.185^{* * *} \\
(0.848)\end{array}$ \\
\hline Observations & 1,116 & 2,304 & 2,233 & 1,725 \\
\hline $\begin{array}{l}\text { Log Likelihood } \\
\theta\end{array}$ & $\begin{array}{c}-2,375.463 \\
0.171^{* * *}(0.010)\end{array}$ & $\begin{array}{c}-4,914.313 \\
0.165^{* * *}(0.007)\end{array}$ & $\begin{array}{c}-4,173.250 \\
0.122^{* * *}(0.005)\end{array}$ & $\begin{array}{c}-2,964.546 \\
0.139^{* * *}(0.007)\end{array}$ \\
\hline Akaike Inf. Crit. & $4,764.926$ & $9,842.626$ & $8,358.499$ & $5,941.092$ \\
\hline
\end{tabular}


Table 5: Fixed effects estimates for upgrade variables, linear models with log(attacks +1$)$

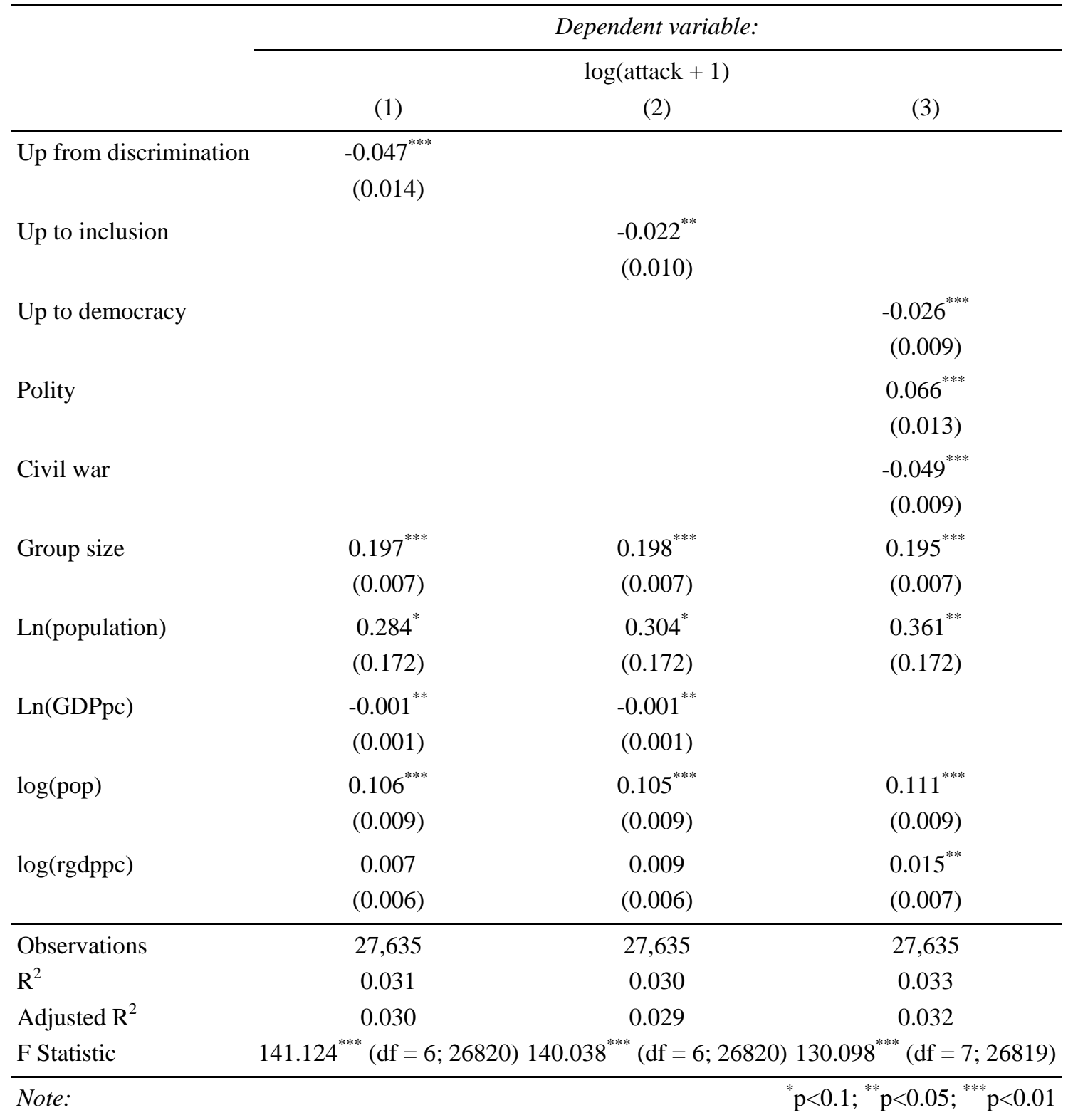


Table 6: Fixed effects estimates, linear models with log(splinter group attacks+1)

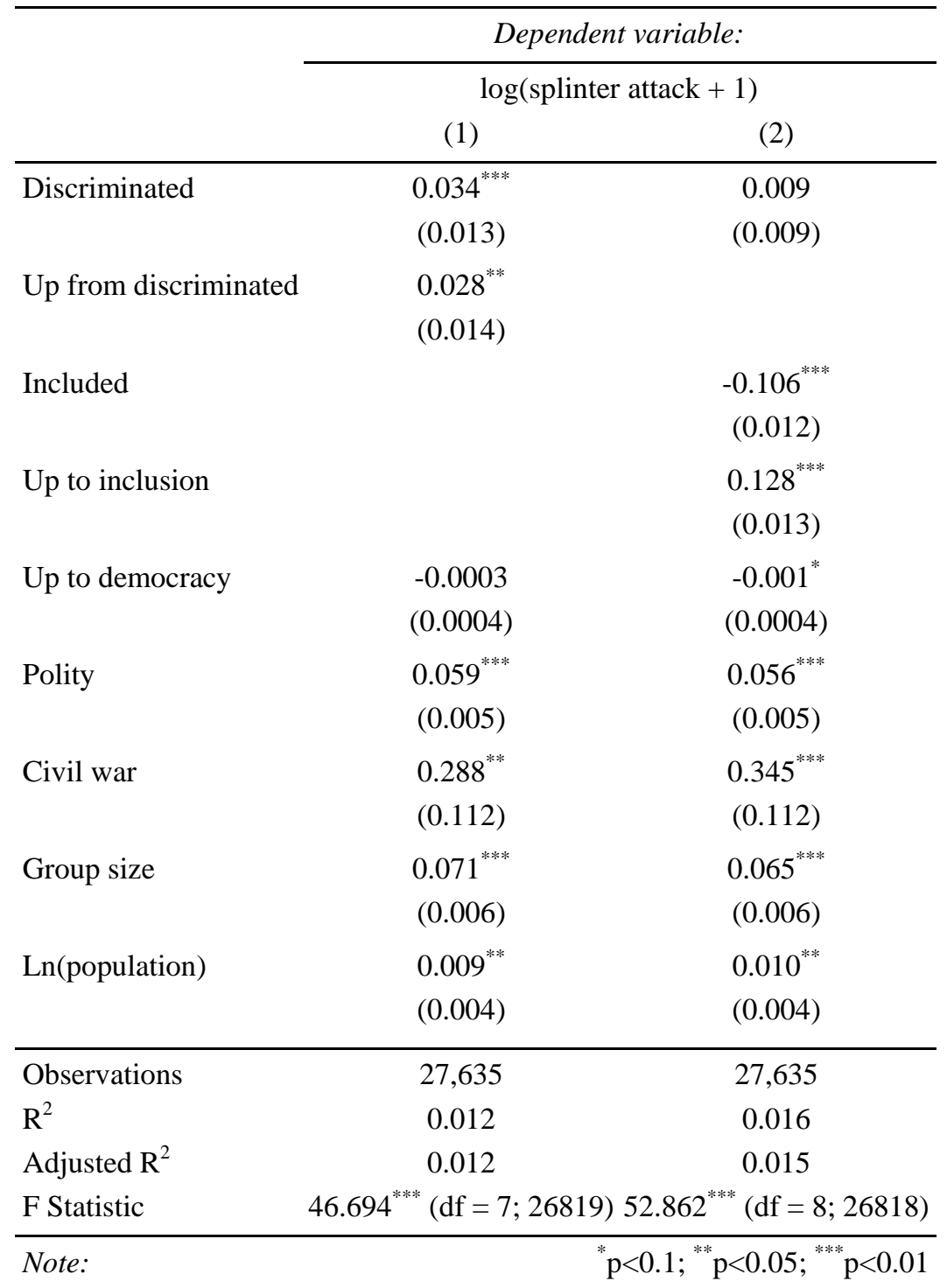




\title{
Supplementary appendix for "Ethnic Inclusion, Democracy, and Terrorism"
}

\author{
Kristian Skrede Gleditsch ${ }^{1,2}$ and Sara M. T. Polo ${ }^{3}$ \\ ${ }^{1}$ University of Essex \\ ${ }^{2}$ Peace Research Institute Oslo (PRIO) \\ ${ }^{3}$ Rice University
}


Table 1: Effect of discrimination and inclusion on ethnic terrorism (levels), allowing for non-linear effect of regime type

\begin{tabular}{|c|c|c|c|}
\hline & \multicolumn{3}{|c|}{ Dependent variable: } \\
\hline & \multicolumn{3}{|c|}{ attack } \\
\hline & (1) & (2) & (3) \\
\hline Discriminated & $\begin{array}{c}0.965^{* * *} \\
(0.153)\end{array}$ & & $\begin{array}{c}0.466^{* * *} \\
(0.160)\end{array}$ \\
\hline Included & & $\begin{array}{c}-0.431^{* * *} \\
(0.104)\end{array}$ & $\begin{array}{c}-0.581^{* * *} \\
(0.120)\end{array}$ \\
\hline Polity & $\begin{array}{c}0.074^{* * *} \\
(0.007)\end{array}$ & $\begin{array}{c}0.080^{* * *} \\
(0.007)\end{array}$ & $\begin{array}{c}0.078^{* * *} \\
(0.007)\end{array}$ \\
\hline Polity sq & $\begin{array}{c}0.014^{* * *} \\
(0.002)\end{array}$ & $\begin{array}{c}0.014^{* * *} \\
(0.002)\end{array}$ & $\begin{array}{c}0.016^{* * *} \\
(0.002)\end{array}$ \\
\hline Civil war & $\begin{array}{c}3.063^{* * *} \\
(0.115)\end{array}$ & $\begin{array}{c}3.042^{* * *} \\
(0.115)\end{array}$ & $\begin{array}{c}3.068^{* * *} \\
(0.116)\end{array}$ \\
\hline Group size & $\begin{array}{c}-0.671^{* * *} \\
(0.190)\end{array}$ & $\begin{array}{c}-0.405^{* *} \\
(0.192)\end{array}$ & $\begin{array}{c}0.009 \\
(0.218)\end{array}$ \\
\hline Ln(population) & $\begin{array}{l}-0.041 \\
(0.028)\end{array}$ & $\begin{array}{l}-0.031 \\
(0.028)\end{array}$ & $\begin{array}{c}0.007 \\
(0.028)\end{array}$ \\
\hline $\operatorname{Ln}(\mathrm{GDPpc})$ & $\begin{array}{c}0.323^{* * *} \\
(0.050)\end{array}$ & $\begin{array}{c}0.267^{* * *} \\
(0.050)\end{array}$ & $\begin{array}{c}0.289^{* * *} \\
(0.050)\end{array}$ \\
\hline Constant & $\begin{array}{c}-5.051^{* * *} \\
(0.483)\end{array}$ & $\begin{array}{c}-4.354^{* * *} \\
(0.483)\end{array}$ & $\begin{array}{c}-4.985^{* * *} \\
(0.482)\end{array}$ \\
\hline Observations & 26,905 & 26,905 & 23,353 \\
\hline Log Likelihood & $-9,126.235$ & $-9,141.362$ & $-8,849.185$ \\
\hline$\theta$ & $0.017^{* * *}(0.001)$ & $0.017^{* * *}(0.001)$ & $0.019^{* * *}(0.001)$ \\
\hline Akaike Inf. Crit. & $18,268.470$ & $18,298.720$ & $17,716.370$ \\
\hline
\end{tabular}


Table 2: Effect of upgrades from discrimination and towards inclusion on ethnic terrorism (changes), allowing for for non-linear effect of regime type

\begin{tabular}{|c|c|c|}
\hline & \multicolumn{2}{|c|}{ Dependent variable: } \\
\hline & \multicolumn{2}{|c|}{ attack } \\
\hline & up from discrim & up to incl \\
\hline & $(1)$ & (2) \\
\hline Up from discrimination & $\begin{array}{c}-0.539^{* * *} \\
(0.173)\end{array}$ & \\
\hline Up to inclusion & & $\begin{array}{l}-0.163 \\
(0.130)\end{array}$ \\
\hline Polity & $\begin{array}{c}0.134^{* * *} \\
(0.014)\end{array}$ & $\begin{array}{c}0.088^{* * *} \\
(0.009)\end{array}$ \\
\hline Polity sq & $\begin{array}{c}0.006^{* *} \\
(0.003)\end{array}$ & $\begin{array}{l}0.0005 \\
(0.002)\end{array}$ \\
\hline Civil war & $\begin{array}{c}1.797^{* * *} \\
(0.160)\end{array}$ & $\begin{array}{c}1.676^{* * *} \\
(0.119)\end{array}$ \\
\hline Group size & $\begin{array}{c}1.977^{* * *} \\
(0.396)\end{array}$ & $\begin{array}{c}0.917^{* * *} \\
(0.332)\end{array}$ \\
\hline Ln(population) & $\begin{array}{l}-0.012 \\
(0.081)\end{array}$ & $\begin{array}{c}-0.249^{* * *} \\
(0.044)\end{array}$ \\
\hline $\operatorname{Ln}(\mathrm{GDPpc})$ & $\begin{array}{c}0.420^{* * *} \\
(0.083)\end{array}$ & $\begin{array}{c}0.605^{* * *} \\
(0.060)\end{array}$ \\
\hline Constant & $\begin{array}{c}-3.073^{* * *} \\
(1.065)\end{array}$ & $\begin{array}{c}-1.784^{* * *} \\
(0.667)\end{array}$ \\
\hline Observations & 1,116 & 2,304 \\
\hline Log Likelihood & $-2,373.562$ & $-4,914.280$ \\
\hline$\theta$ & $0.172^{* * *}(0.010)$ & $0.165^{* * *}(0.007)$ \\
\hline Akaike Inf. Crit. & $4,763.124$ & $9,844.561$ \\
\hline
\end{tabular}


Table 3: Effect of discrimination and inclusion (fixed effects), allowing for non-linear effect of regime type

\begin{tabular}{|c|c|c|}
\hline & \multicolumn{2}{|c|}{ Dependent variable: } \\
\hline & \multicolumn{2}{|c|}{$\log (\operatorname{attack}+1)$} \\
\hline & $(1)$ & $(2)$ \\
\hline Discriminated & $\begin{array}{c}0.068^{* * *} \\
(0.014)\end{array}$ & \\
\hline Included & $\begin{array}{c}-0.049^{* * *} \\
(0.009)\end{array}$ & \\
\hline Up from discrim & & $\begin{array}{c}-0.044^{* * *} \\
(0.014)\end{array}$ \\
\hline Polity & $\begin{array}{c}-0.001^{*} \\
(0.001)\end{array}$ & $\begin{array}{c}-0.001^{* *} \\
(0.001)\end{array}$ \\
\hline Polity sq & $\begin{array}{l}-0.0001 \\
(0.0001)\end{array}$ & $\begin{array}{l}-0.0002 \\
(0.0001)\end{array}$ \\
\hline Civil war & $\begin{array}{c}0.194^{* * *} \\
(0.007)\end{array}$ & $\begin{array}{c}0.197^{* * *} \\
(0.007)\end{array}$ \\
\hline Group size & $\begin{array}{l}0.357^{* *} \\
(0.172)\end{array}$ & $\begin{array}{c}0.285^{*} \\
(0.172)\end{array}$ \\
\hline $\operatorname{Ln}$ (population) & $\begin{array}{c}0.109^{* * *} \\
(0.009)\end{array}$ & $\begin{array}{c}0.104^{* * *} \\
(0.009)\end{array}$ \\
\hline $\operatorname{Ln}(\mathrm{GDPpc})$ & $\begin{array}{l}0.015^{* *} \\
(0.007)\end{array}$ & $\begin{array}{c}0.008 \\
(0.006)\end{array}$ \\
\hline Observations & 27,635 & 27,635 \\
\hline $\mathrm{R}^{2}$ & 0.033 & 0.031 \\
\hline Adjusted $\mathrm{R}^{2}$ & 0.032 & 0.030 \\
\hline F Statistic & $113.165^{* * *}(\mathrm{df}=8 ; 26818)$ & $121.292^{* * *}(\mathrm{df}=7 ; 26819)$ \\
\hline
\end{tabular}


Table 4: Estimates for effects of democracy and transitions conditional on group size

\begin{tabular}{|c|c|c|c|}
\hline & \multicolumn{3}{|c|}{ Dependent variable: } \\
\hline & $(1)$ & $\begin{array}{l}\text { attack } \\
(2) \\
\end{array}$ & $\begin{array}{c}\text { W/o Asia } \\
\text { (3) }\end{array}$ \\
\hline Discriminated & $\begin{array}{c}0.783^{* * *} \\
(0.157)\end{array}$ & & \\
\hline Included & $\begin{array}{c}-0.293^{* *} \\
(0.118)\end{array}$ & & \\
\hline Democracy & $\begin{array}{c}1.602^{* * *} \\
(0.144)\end{array}$ & & \\
\hline Up to democracy & & $\begin{array}{c}0.856^{* * *} \\
(0.186)\end{array}$ & $\begin{array}{c}0.132 \\
(0.210)\end{array}$ \\
\hline Civil war & $\begin{array}{c}1.849^{* * *} \\
(0.262)\end{array}$ & $\begin{array}{c}1.036^{* * *} \\
(0.337)\end{array}$ & $\begin{array}{c}0.985^{* * *} \\
(0.342)\end{array}$ \\
\hline Group size & $\begin{array}{c}3.012^{* * *} \\
(0.115)\end{array}$ & $\begin{array}{c}1.830^{* * *} \\
(0.138)\end{array}$ & $\begin{array}{c}1.887^{* * *} \\
(0.152)\end{array}$ \\
\hline Ln(population) & $\begin{array}{c}0.029 \\
(0.028)\end{array}$ & $\begin{array}{c}-0.196^{* * *} \\
(0.057)\end{array}$ & $\begin{array}{c}-0.287^{* * *} \\
(0.067)\end{array}$ \\
\hline $\operatorname{Ln}(G D P p c)$ & $\begin{array}{c}0.619^{* * *} \\
(0.049)\end{array}$ & $\begin{array}{c}0.626^{* * *} \\
(0.067)\end{array}$ & $\begin{array}{c}1.091^{\text {*** }} \\
(0.072)\end{array}$ \\
\hline Democracy X group size & $\begin{array}{c}-9.960^{* * *} \\
(0.704)\end{array}$ & & \\
\hline Up to democracy $X$ group size & & $\begin{array}{c}-2.194^{* * *} \\
(0.707)\end{array}$ & $\begin{array}{c}-3.333^{* * *} \\
(0.759)\end{array}$ \\
\hline Constant & $\begin{array}{c}-7.628^{* * *} \\
(0.488)\end{array}$ & $\begin{array}{c}-2.783^{* * *} \\
(0.754)\end{array}$ & $\begin{array}{c}-5.849^{* * *} \\
(0.803)\end{array}$ \\
\hline Observations & 23,353 & 2,233 & 1,725 \\
\hline Log Likelihood & $-8,808.962$ & $-4,171.110$ & $-2,958.212$ \\
\hline$\theta$ & $0.020^{* * *}(0.001)$ & $0.123^{* * *}(0.005)$ & $0.142^{* * *}(0.007)$ \\
\hline Akaike Inf. Crit. & $17,635.920$ & $8,356.220$ & $5,930.424$ \\
\hline
\end{tabular}


Table 5: Effect of discrimination and inclusion. Two-level mixed effects negative binomial (grouplevel clusters)

\begin{tabular}{|c|c|c|c|c|c|}
\hline & All groups & All groups & Pol. relevant & Pol. relevant & Pol. relevant \\
\hline Discriminated & $\begin{array}{l}0.757^{* * *} \\
(0.187)\end{array}$ & & $\begin{array}{l}0.732^{* * *} \\
(0.192)\end{array}$ & & $\begin{array}{l}0.598^{* * *} \\
(0.204)\end{array}$ \\
\hline Included & & $\begin{array}{c}-0.469^{* * *} \\
(0.149)\end{array}$ & & $\begin{array}{c}-0.479^{* * *} \\
(0.151)\end{array}$ & $\begin{array}{c}-0.319^{* *} \\
(0.160)\end{array}$ \\
\hline Democracy & $\begin{array}{l}0.035^{* * *} \\
(0.011)\end{array}$ & $\begin{array}{l}0.037^{* * *} \\
(0.011)\end{array}$ & $\begin{array}{l}0.037^{* * *} \\
(0.011)\end{array}$ & $\begin{array}{l}0.039^{* * *} \\
(0.011)\end{array}$ & $\begin{array}{l}0.040^{* * *} \\
(0.011)\end{array}$ \\
\hline Civil war & $\begin{array}{l}2.647^{* * *} \\
(0.135)\end{array}$ & $\begin{array}{l}2.692^{\text {*** }} \\
(0.134)\end{array}$ & $\begin{array}{l}2.707^{* * *} \\
(0.136)\end{array}$ & $\begin{array}{l}2.749^{* * *} \\
(0.135)\end{array}$ & $\begin{array}{l}2.704^{* * *} \\
(0.136)\end{array}$ \\
\hline Group size & $\begin{array}{l}1.631^{* *} \\
(0.750)\end{array}$ & $\begin{array}{l}1.792^{* *} \\
(0.755)\end{array}$ & $\begin{array}{l}2.095^{* * *} \\
(0.796)\end{array}$ & $\begin{array}{l}2.322^{* * *} \\
(0.806)\end{array}$ & $\begin{array}{l}2.309^{* * *} \\
(0.803)\end{array}$ \\
\hline Population (log) & $\begin{array}{l}0.744^{* * *} \\
(0.125)\end{array}$ & $\begin{array}{l}0.785^{\text {*** }} \\
(0.129)\end{array}$ & $\begin{array}{l}0.789^{* * *} \\
(0.127)\end{array}$ & $\begin{array}{l}0.815^{\text {*** }} \\
(0.129)\end{array}$ & $\begin{array}{l}0.826^{* * *} \\
(0.130)\end{array}$ \\
\hline Ral GDP pc (log) & $\begin{array}{r}-0.042 \\
(0.124)\end{array}$ & $\begin{array}{c}0.003 \\
(0.124)\end{array}$ & $\begin{array}{r}-0.024 \\
(0.126)\end{array}$ & $\begin{array}{c}0.005 \\
(0.127)\end{array}$ & $\begin{array}{c}0.002 \\
(0.127)\end{array}$ \\
\hline Constant & $\begin{array}{c}-19.173^{* * *} \\
(1.857)\end{array}$ & $\begin{array}{c}-19.895^{* * *} \\
(1.935)\end{array}$ & $\begin{array}{c}-19.473^{* * *} \\
(1.892)\end{array}$ & $\begin{array}{c}-19.745^{* * *} \\
(1.939)\end{array}$ & $\begin{array}{c}-19.912^{* * *} \\
(1.936)\end{array}$ \\
\hline lnalpha & $\begin{array}{l}1.695^{\text {*** }} \\
(0.040)\end{array}$ & $\begin{array}{l}1.693^{\text {*** }} \\
(0.040)\end{array}$ & $\begin{array}{l}1.668^{* * *} \\
(0.040)\end{array}$ & $\begin{array}{l}1.667^{* * *} \\
(0.040)\end{array}$ & $\begin{array}{l}1.666^{* * *} \\
(0.040)\end{array}$ \\
\hline$\sigma_{\text {group }}^{2}$ & $\begin{array}{l}55.429^{* * *} \\
(8.748)\end{array}$ & $\begin{array}{l}58.267^{* * *} \\
(9.223)\end{array}$ & $\begin{array}{l}51.490^{* * *} \\
(8.383)\end{array}$ & $\begin{array}{l}52.468^{* * *} \\
(8.594)\end{array}$ & $\begin{array}{l}51.332^{\text {*** }} \\
(8.438)\end{array}$ \\
\hline $\begin{array}{l}\text { Wald } \chi^{2} \\
\text { Log-Likelihood } \\
\text { Number of observations }\end{array}$ & $\begin{array}{l}\quad 463.01^{* * *} \\
-6907.08 \\
26905\end{array}$ & $\begin{array}{l}456.19^{* * *} \\
-6910.37 \\
26905\end{array}$ & $\begin{array}{l}\quad 475.47^{* * *} \\
-6781.51 \\
23353\end{array}$ & $\begin{array}{rl} & 470.65^{* * *} \\
- & 6783.68 \\
2 & 3353\end{array}$ & $\begin{array}{l}\quad 475.48^{* * *} \\
-6779.35 \\
23353\end{array}$ \\
\hline
\end{tabular}

$* \mathrm{p}<0.1, * * \mathrm{p}<0.05, * * * \mathrm{p}<0.01$ 
Table 6: Effect of upgrades. Two-level mixed effects negative binomial (group-level clusters)

\begin{tabular}{|c|c|c|c|}
\hline & & attack & \\
\hline Up from discrimination & $\begin{array}{c}-0.987^{* * *} \\
(0.203)\end{array}$ & & \\
\hline Up to inclusion & & $\begin{array}{c}-0.606^{* * *} \\
(0.159)\end{array}$ & \\
\hline Up to democracy & & & $\begin{array}{c}-0.781^{* * *} \\
(0.168)\end{array}$ \\
\hline Democracy & $\begin{array}{r}-0.033^{*} \\
(0.020)\end{array}$ & $\begin{array}{c}0.000 \\
(0.013)\end{array}$ & \\
\hline Civil war & $\begin{array}{l}1.514^{* * *} \\
(0.170)\end{array}$ & $\begin{array}{l}1.755^{* * *} \\
(0.134)\end{array}$ & $\begin{array}{l}1.951^{* * *} \\
(0.145)\end{array}$ \\
\hline Group size & $\begin{array}{c}3.801^{* *} \\
(1.576)\end{array}$ & $\begin{array}{r}2.246^{*} \\
(1.328)\end{array}$ & $\begin{array}{c}1.063 \\
(1.006)\end{array}$ \\
\hline Population (log) & $\begin{array}{c}-0.874^{* * *} \\
(0.323)\end{array}$ & $\begin{array}{c}-0.536^{* * *} \\
(0.199)\end{array}$ & $\begin{array}{c}-0.556^{* * *} \\
(0.181)\end{array}$ \\
\hline Real GDP pc (log) & $\begin{array}{c}-0.071 \\
(0.246)\end{array}$ & $\begin{array}{c}0.097 \\
(0.149)\end{array}$ & $\begin{array}{c}0.233 \\
(0.154)\end{array}$ \\
\hline Constant & $\begin{array}{l}8.017^{* *} \\
(3.612)\end{array}$ & $\begin{array}{c}3.696 \\
(2.372)\end{array}$ & $\begin{array}{c}2.539 \\
(2.068)\end{array}$ \\
\hline $\ln \alpha$ & $\begin{array}{l}0.786^{* * *} \\
(0.072)\end{array}$ & $\begin{array}{l}0.914^{* * *} \\
(0.049)\end{array}$ & $\begin{array}{l}1.031^{* * *} \\
(0.054)\end{array}$ \\
\hline$\hat{\sigma}_{\text {group }}^{2}$ & $\begin{array}{l}7.973^{* * *} \\
(2.249)\end{array}$ & $\begin{array}{l}6.966^{* * *} \\
(1.445)\end{array}$ & $\begin{array}{l}6.109^{* * *} \\
(1.088)\end{array}$ \\
\hline Wald $\chi^{2}$ & $200.71^{* * *}$ & $217.36^{* * *}$ & $239.54^{* * *}$ \\
\hline Log-Likelihood & -2166.89 & -4509.36 & -3761.80 \\
\hline Number of observations & 1116 & 2304 & 2233 \\
\hline
\end{tabular}

$* \mathrm{p}<0.1,{ }^{*} * \mathrm{p}<0.05, * * * \mathrm{p}<0.01$ 
Table 7: Effect of upgrades. Three-level mixed effects negative binomial (group-level and countrylevel clusters)

\begin{tabular}{|c|c|c|c|}
\hline & upfromdisc & uptoincl & uptodem \\
\hline Up from discrimination & $\begin{array}{c}-0.938^{* * *} \\
(0.205)\end{array}$ & & \\
\hline Up to inclusion & & $\begin{array}{c}-0.544^{* * *} \\
(0.161)\end{array}$ & \\
\hline Up to democracy & & & $\begin{array}{c}-0.789^{* * *} \\
(0.169)\end{array}$ \\
\hline Democracy & $\begin{array}{r}-0.032 \\
(0.020)\end{array}$ & $\begin{array}{r}-0.003 \\
(0.013)\end{array}$ & \\
\hline Civil war & $\begin{array}{l}1.512^{\text {*** }} \\
(0.170)\end{array}$ & $\begin{array}{c}1.735^{* * *} \\
(0.136)\end{array}$ & $\begin{array}{c}1.982^{\text {*** }} \\
(0.147)\end{array}$ \\
\hline Group size & $\begin{array}{c}3.288^{* *} \\
(1.356)\end{array}$ & $\begin{array}{c}2.003 \\
(1.456)\end{array}$ & $\begin{array}{c}0.817 \\
(1.036)\end{array}$ \\
\hline Population (log) & $\begin{array}{c}-1.158^{* * *} \\
(0.391)\end{array}$ & $\begin{array}{c}-1.215^{\text {*** }} \\
(0.370)\end{array}$ & $\begin{array}{c}-0.732^{* * *} \\
(0.233)\end{array}$ \\
\hline Ral GDP pc (log) & $\begin{array}{r}-0.174 \\
(0.269)\end{array}$ & $\begin{array}{c}0.015 \\
(0.168)\end{array}$ & $\begin{array}{c}0.089 \\
(0.169)\end{array}$ \\
\hline Constant & $\begin{array}{l}11.656^{* * *} \\
(4.087)\end{array}$ & $\begin{array}{l}11.020^{\text {*** }} \\
(3.601)\end{array}$ & $\begin{array}{c}5.381^{* *} \\
(2.540)\end{array}$ \\
\hline lnalpha & $\begin{array}{l}0.776^{* * *} \\
(0.072)\end{array}$ & $\begin{array}{c}0.888^{* * *} \\
(0.049)\end{array}$ & $\begin{array}{l}1.023^{* * *} \\
(0.054)\end{array}$ \\
\hline$\sigma_{\text {country }}^{2}$ & $\begin{array}{c}8.585^{* *} \\
(3.717)\end{array}$ & $\begin{array}{c}8.101^{* *} \\
(3.815)\end{array}$ & $\begin{array}{c}2.570^{* *} \\
(1.274)\end{array}$ \\
\hline$\sigma_{\text {group }}^{2}$ & $\begin{array}{c}2.215^{* *} \\
(0.911)\end{array}$ & $\begin{array}{l}3.755^{\text {*** }} \\
(0.872)\end{array}$ & $\begin{array}{l}4.253^{\text {*** }} \\
(0.881)\end{array}$ \\
\hline Wald $\chi^{2}$ & $203.88^{* * *}$ & $230.35^{* * *}$ & $244.18^{* * *}$ \\
\hline Log-Likelihood & -2161.36 & -4498.67 & -3756.30 \\
\hline Number of observations & 1116 & 2304 & 2233 \\
\hline
\end{tabular}

$* \mathrm{p}<0.1, * * \mathrm{p}<0.05, * * * \mathrm{p}<0.01$ 